\title{
Morphology, ultrastructure and molecular phylogeny of cyst-producing Caladoa arcachonensis gen. et sp. nov. (Peridiniales, Dinophyceae) from France and Indonesia
}

\author{
Luo Zhaohe ${ }^{1}$, Mertens Kenneth ${ }^{2,{ }^{*},}$ Nezan Elisabeth ${ }^{2}$, Gu Li ${ }^{1}$, Pospelova Vera ${ }^{3}$, Thoha Hikmah ${ }^{4,}$, \\ Gu Haifeng ${ }^{1}$
}

${ }^{1}$ Minist Nat Resources, Inst Oceanog 3, Xiamen 361005, Peoples R China.

2 IFREMER, LER BO, Stn Biol Marine, PI Croix,BP40537, F-29185 Concarneau, France.

${ }^{3}$ Univ Victoria, Sch Earth \& Ocean Sci, OEASB A405,POB 170016 STN CSC, Victoria, BC V8W 2Y2, Canada.

${ }^{4}$ Indonesian Inst Sci, Res Ctr Oceanog, Jakarta 14430, Indonesia.

* Corresponding authors: Kenneth Mertens, email address : kenneth.mertens@ifremer.fr ; Hikmah Thoha, email address : guhaifeng@tio.org.cn

\begin{abstract}
:
The dinoflagellate order Peridiniales encompasses several well circumscribed families. However, the family level of some genera, such as Bysmatrum and Vulcanodinium, has remained elusive for many years. Four Peridinium-like strains were established from the Atlantic coast of France and North Sulawesi, Indonesia through cyst germination or isolation of single cells. The cyst-theca relationship was established on specimens from the French Atlantic. Their morphologies were examined using light, scanning and transmission electron microscopy. The cells were characterized by a much larger epitheca relative to the hypotheca, a large anterior sulcal (Sa) plate deeply intruding the epitheca and a small first anterior intercalary plate. The plate formula was identified as Po, cp, X, 4', 3a, 7", 6C, 5S, 5"', 2"'", shared by Apocalathium, Chimonodinium, Fusiperidinium and Scrippsiella of the family Thoracosphaeraceae but the configuration of Sa plate and anterior intercalary plates is different. Transmission electron microscopy showed that the eyespot was located within a chloroplast comprising two rows of lipid globules and thus belongs to type A. All four strains were classified within a new genus Caladoa as $C$. arcachonensis gen. et sp. nov. Small subunit ribosomal DNA (SSU rDNA), partial large subunit ribosomal DNA (LSU rDNA) and internal transcribed spacer ribosomal DNA (ITS rDNA) sequences were obtained from all strains. Genetic distance based on ITS rDNA sequences between French and Indonesian strains reached 0.17 , suggesting cryptic speciation in $C$. arcachonensis. The maximum likelihood and Bayesian inference analysis based on concatenated data from SSU and LSU rDNA sequences revealed that Caladoa is monophyletic and closest to Bysmatrum. Our results supported that Caladoa and Bysmatrum are members of the order Peridiniales but their family level remains to be determined. Our results also support that Vulcanodinium is closest to the family Peridiniaceae.
\end{abstract}

Keywords : Bysmatrum, cyst, dinoflagellate, eyespot, Peridiniales, plate overlap 
45

46

47

48

49

50

51

52

53

54

55

56

57

58

59

60

61

62

63

64

65

\section{Introduction}

The dinoflagellate order Peridiniales is characterized by a symmetrical first apical plate

and two more or less symmetrical antapical plates (Fensome et al., 1993). Peridiniales

currently encompasses several families including Blastodiniaceae, Heterocapsaceae,

Kryptoperidiniaceae, Peridiniaceae, Peridiniopsidaceae, Protoperidiniaceae,

Thoracosphaeraceae and Zooxanthellaceae (Gottschling et al., 2017). The morphological

features in some of these families are well circumscribed, e.g. Peridiniopsidaceae has six

cingular plates and less than two anterior intercalary plates (Gottschling et al., 2017);

Protoperidiniaceae has three cingular plates and one transitional plate (Fensome et al.,

1993). In other families, however, morphological features are not well defined. For

instance, Kryptoperidiniaceae includes species with one or two anterior intercalary plates

(Pienaar et al., 2007; Saburova et al., 2012; You et al., 2015), but some genera (e.g.

Galeidinium M.Tamura \& T. Horiguchi) do not show any thecal plate pattern (Tamura et

al., 2005). The family Thoracosphaeraceae has unified the subfamily Calciodinelloideae

and the order Thoracosphaerales, but its emended description was not provided by

Elbrächter et al., (2008).

Information on the evolutionary history and cell ultrastructure are important for

systematics, even at the family level. For instance, Kryptoperidiniaceae includes a small

group of dinoflagellates hosting a tertiary endosymbiont derived from a diatom

(Horiguchi \& Takano, 2006; Kretschmann et al., 2018). Kryptoperidiniaceae currently

includes Durinskia S. Carty \& E.R. Cox, Blixaea M. Gottschling, Galeidinium, 
66 Kryptoperidinium Lindemann, and Unruhdinium M. Gottschling. All these genera share a

67 type D eyespot (Tamura et al., 2005; You et al., 2015; Yamada et al., 2017) that was

68 likely derived from the original dinoflagellate chloroplast (Moestrup \& Daugbjerg, 2007).

69 The woloszynskioid dinoflagellates families Tovelliaceae and Borghiellaceae are

70 characterized by a type $\mathrm{C}$ eyespot (composed of pigment globules not bound by

71 membranes outside of the chloroplast) (Lindberg et al., 2005) and by a type B eyespot

72 (intraplastidic with bricklike crystals overlying the chloroplast), respectively (Moestrup et

73 al., 2009). In addition to the eyespot, peduncle microtubules were also suggested to be

74 one of the diagnostic features to separate Peridiniopsidaceae from Peridiniaceae

75 (Gottschling et al., 2017).

76

77

Among 2000 extant dinoflagellate species, only $13 \%$ to $16 \%$ of the motile stages

78 have been related to resting cysts (Head, 1996). Cyst morphologies are often considered

79 to be useful at interspecific level, e.g. Protoperidinium Bergh produces a number of cysts

80 classified within different cyst genera (Gu et al., 2015), but also at the generic level, e.g.

81 cysts of Biecheleria Ø. Moestrup, K. Lindberg \& N. Daugbjerg are spherical and

82 bearnumerous short processes (Moestrup et al., 2009), or even at the subfamily level, e.g.

83 Calciodinelloideae is characterized by possessing calcareous cysts (Elbrächter et al., 84 2008).

85 Molecularly, more than $90 \%$ of peridinialean species can be reliably placed into one 86 of the families of Peridiniales (Gottschling et al., 2017), but some genera (e.g. 
87 Bysmatrum M.A. Faust \& K.A. Steidinger, Vulcanodinium E. Nézan \& N. Chomérat)

88 have not been identified to the family level yet, although they display a peridinialean

89 tabulation. Vulcanodinium was reported to be closely related with Peridinium cinctum

90 (O.F. Müller) C.G. Ehrenberg based on LSU sequences (Nézan \& Chomérat, 2011) and

91 concatenated data from SSU, ITS and LSU sequences (Luo et al., 2018), but whether

92 Vulcanodinium is also a member of Peridiniaceae is not clear. The phylogenetic position

93 of Bysmatrum is elusive too: it is close to Peridinium C.G. Ehrenberg with low support in

94 the phylogeny based on concatenated data from SSU, ITS and LSU sequences (Anglès et

95 al., 2017; Luo et al., 2018), but sometimes it is closer to Prorocentrum C.G. Ehrenberg

96 (Gottschling et al., 2012; Dawut et al., 2018).

97 To clarify the phylogenetic positions of Vulcanodinium and Bysmatrum, sequences

98 from closely related species of these two genera are essential. In the present study, four

99 strains of Peridinium-like species were established from the Atlantic coast of France and

100 North Sulawesi, Indonesia by incubating cysts or isolating single cells. The four cultured

101 strains were examined morphologically and ultrastructurally, the latter with an emphasis

102 on the eyespot. In addition, small subunit ribosomal DNA (SSU rDNA), partial large

103 subunit ribosomal DNA (LSU rDNA) and internal transcribed spacer ribosomal DNA

104 (ITS rDNA) sequences were determined for the cultured strains and molecular phylogeny

105 was inferred using concatenated SSU and LSU rDNA sequences.

106 


\section{$107 \quad$ Material and methods}

108

109

110

111

112

113

114

115

116

117

118

119

120

121

122

123

124

125

\section{Sample collection and treatment}

Seagrass and sand samples were collected from the seabed by scuba divers near Manado and Bitung, North Sulawesi of Indonesia on July 31 and August 1, 2016 and placed into bottles containing seawater from the same location. The samples were stirred vigorously to detach the epibenthic cells and the suspension settled in a composite settling chamber. The settled material was rinsed with filtered seawater and transferred into a polycarbonate bottle. Single Peridinium-like cells were isolated from this material and the strains TIO339 and TIO340 were established (Table 1).

Sediment sampling was done using an Ekman grab on April 15 and 19, 2016 in a shallow natural reservoir used for oyster storage before commercialization (water depth $1.2-1.5 \mathrm{~m})$. The small basin is located in Arcachon Bay in the Gironde region of southwestern France. The top $2 \mathrm{~cm}$ of sediment were sliced off and stored in the dark at 4 ${ }^{\circ} \mathrm{C}$ until further treatment. Approximately $5 \mathrm{~g}$ of wet sediment was mixed with $20 \mathrm{~mL}$ of filtered seawater and stirred vigorously to dislodge detrital particles. The settled material was subsequently sieved through $120 \mu \mathrm{m}$ and $10 \mu \mathrm{m}$ filters. Single cysts were isolated with a micropipette using an inverted Eclipse TS100 (Nikon, Tokyo, Japan) microscope, alternatively small quantity of sediment was directly incubated in small containers with f/2-Si medium (Guillard \& Ryther, 1962) at $20^{\circ} \mathrm{C}, 90 \mu \mathrm{E} \cdot \mathrm{m}^{-2} \cdot \mathrm{s}^{-1}$ under a $12: 12 \mathrm{~h}$ light: 
126 dark cycle. The strains TIO278 and TIO282 were established using direct incubation

127 (Table 1).

128

Morphological study of motile cells with microscopy

129

130 Live cells were examined and photographed using a Zeiss Axio Imager light microscope

131 (Carl Zeiss, Göttingen, Germany) equipped with a Zeiss Axiocam HRc digital camera.

132 The size of 30 cells was measured using Axiovision (4.8.2 version) software at $\times 1000$

133 magnification. To observe the shape and location of the nucleus, cells were stained with

134 1:100,000 SYBR Green (Sigma Aldrich, St. Louis, USA) for $1 \mathrm{~min}$, and photographed

135 using the Zeiss fluorescence microscope with a Zeiss-38 filter set (excitation BP 470/40,

136 beam splitter FT 495, emission BP 525/50). Chloroplast autofluorescence microscopy

137 was carried out on live cells using the above mentioned microscope equipped with a

138 Chroma filter cube (emission filter ET480/20x, dichromatic mirror AT505dc, suppression

139 filter AT5151p), and digitally photographed using a Zeiss Axiocam HRc digital camera.

140 For scanning electron microscopy (SEM), mid-exponential batch cultures of four

141 strains were concentrated by a Universal 320 R centrifuge (Hettich-Zentrifugen,

142 Tuttlingen, Germany) at $850 \mathrm{~g}$ for $10 \mathrm{~min}$ at room temperature. Cells were fixed with

$1432.5 \%$ glutaraldehyde for $3 \mathrm{~h}$ at $8^{\circ} \mathrm{C}$, rinsed with Milli-Q water twice and post-fixed with

$1441 \% \mathrm{OsO}_{4}$ overnight at $8^{\circ} \mathrm{C}$ in a tube. The supernatant was removed and the settled cells

145 were transferred to a coverslip coated with poly-L-lysine (molecular weight 
146 70,000-150,000). The cells attached to the cover slip were rinsed in Milli-Q water twice.

147 The samples were then dehydrated in a graded ethanol series $(10,30,50,70,90$ and $3 \times$ in

$148100 \%, 10$ min at each step), critical point dried (K850 Critical Point Dryer,

149 Quorum/Emitech, West Sussex, UK), sputter-coated with gold, and examined with a

150 Zeiss Sigma FE (Carl Zeiss Inc., Oberkochen, Germany) scanning electron microscope.

151 Labelling of tabulation follows a modified Kofoid system (Fensome et al., 1993), and the

152 sulcal plate labelling is according to Balech (1980).

153 Transmission electron microscopy (TEM)

154 Mid-exponential batch cultures of strain TIO278 (France) were fixed in 2.5\%

155 glutaraldehyde in phosphate buffer saline (PBS, $0.1 \mathrm{M}$ at $\mathrm{pH} 7.4$ ) for $1 \mathrm{~h}$, concentrated by

156 centrifugation and then washed three times with the same PBS for 10 min each. They

157 were post-fixed in $1 \% \mathrm{OsO}_{4}$ overnight at $4^{\circ} \mathrm{C}$ and washed three times with the same PBS

158 for $10 \mathrm{~min}$ each. The cells were then dehydrated through a graded ethanol series $(10,30$,

$15950,70,95,3 \times$ in $100 \%, 10$ min at each step). The pellet was embedded in Spurr's resin

160 (Spurr, 1969) and sectioned with a Reichert Ultracut E microtome (Leica, Vienna,

161 Austria), mounted on Formvar-coated grids, stained with uranyl acetate and lead citrate,

162 and observed in a JEOL JEM-100 transmission electron microscope (JEOL, Tokyo,

163 Japan). 
164

165

166

167

168

169

170

171

172

173

174

175

176

177

178

179

180

181

182

\section{PCR amplifications and sequencing}

The total algal DNA was extracted from $10 \mathrm{~mL}$ of exponentially growing cultures using a

MiniBEST Universal DNA Extraction Kit (Takara, Tokyo, Japan) according to the

manufacturer's protocol. PCR amplifications were carried out using $1 \times$ PCR buffer, 50

$\mu \mathrm{M}$ dNTP mixture, $0.2 \mu \mathrm{M}$ of each primer, $10 \mathrm{ng}$ of template genomic DNA, and $1 \mathrm{U}$ of

ExTaq DNA Polymerase (Takara, Tokyo, Japan) in $50 \mu \mathrm{L}$ reactions. The SSU rDNA was

amplified using the primers of PRIMER A/PRIMER B (Medlin et al. 1988). The LSU

rDNA was amplified using the primers of D1R/28-1483R (Scholin et al., 1994;

Daugbjerg et al., 2000). The total ITS1-5.8S-ITS2 was amplified using ITSA/ITSB

primers (Adachi et al., 1996). The thermal cycle procedure was 4 min at $94^{\circ} \mathrm{C}$, followed

by 30 cycles of $1 \mathrm{~min}$ at $94^{\circ} \mathrm{C}, 1 \mathrm{~min}$ at $45^{\circ} \mathrm{C}, 1 \mathrm{~min}$ at $72^{\circ} \mathrm{C}$, and final extension of $7 \mathrm{~min}$

at $72^{\circ} \mathrm{C}$ with a Mastercycler (Eppendorf, Hamburg, Germany). The PCR product was

purified using a SanPrep Column DNA Gel Extraction Kit (Sangon Biotech, Shanghai, China)

and sequenced directly in both directions on an ABI PRISM 3730XL (Applied

Biosystems, Foster City, CA, USA) following the manufacturer's instructions. Newly

obtained sequences were deposited in GenBank with accession numbers MK012070 to

MK012084.

Sequence alignment and phylogenetic analysis

Newly obtained sequences (SSU and partial LSU rDNA) were incorporated into a 
183 systematically representative set of dinoflagellates available in GenBank. Sequences were 184 aligned using MAFFT v7.110 (Katoh \& Standley, 2013) online program 185 (http://mafft.cbrc.jp/alignment/server/) with default settings. Alignments were manually 186 checked with BioEdit v. 7.0 .5 (Hall, 1999). For Bayesian inference (BI), the program 187 jModelTest (Posada, 2008) was used to select the most appropriate model of molecular 188 evolution with Akaike Information Criterion (AIC). Bayesian reconstruction of the data 189 matrix was performed using MrBayes 3.2 (Ronquist \& Huelsenbeck, 2003) with the 190 best-fitting substitution model $(\mathrm{GTR}+\mathrm{G})$. Four Markov chain Monte Carlo (MCMC) 191 chains ran for 2,000,000 generations, sampling every 100 generations. The first $10 \%$ of 192 burn-in trees were discarded. A majority rule consensus tree was created in order to 193 examine the posterior probabilities of each clade. Maximum likelihood (ML) analyses 194 were conducted with RaxML v7.2.6 (Stamatakis, 2006) on the T-REX web server (Boc et 195 al., 2012) using the model GTR + G. Node support was assessed with 1000 bootstrap 196 replicates.

197 Multiple ITS1-5.8S-ITS2 sequences of new strains were aligned using MAFFT v7.110 198 (Katoh \& Standley, 2013) online program with default settings. Completed alignments 199 were saved as NEXUS files and imported into PAUP*4b10 software (Swofford, 2002) to 200 estimate divergence rates using simple uncorrected pairwise (p) distance matrices. 201

\section{Results}


204 DIAGNOSIS: Cells with a plate formula of Po, cp, X, 4', 3a, 7", 6C, 5S, 5'"', 2"'". A

205 large anterior sulcal plate deeply intrudes the epitheca. Chloroplasts with a stalked

206 pyrenoid and a type A eyespot is present. Cells differ from Chimonodinium,

207 Fusiperidinium, Apocalathium, Scrippsiella, Vulcanodinium and Bysmatrum in the size

208 and location of Sa plate and from Peridinium by the presence of an additional cingular

209 plate.

210 ETYMOLOGY: The epithet Caladoa is named after António José Calado, who

211 carried out outstanding work on freshwater dinoflagellate taxonomy.

212 TYPE SPECIES: Caladoa arcachonensis Z. Luo, K.N. Mertens \& H.F. Gu

213

214 Caladoa arcachonensis Z. Luo, K.N. Mertens \& H.F. Gu sp. nov. (Figs. 1-26)

215 DIAGNOSIS: Cells are 16.7-23.5 $\mu \mathrm{m}$ long and 13.1-19.4 $\mu \mathrm{m}$ wide. The cells have

216 a rounded epitheca and hypotheca with an epitheca: hypotheca length ratio of 1.5-1.8.

217 The thecae display a plate formula of Po, cp, X, 4', 3a, 7", 6C, 5S, 5'"', 2'"'. A large

218 anterior sulcal plate deeply intrudes in the epitheca. Plate 1a is about half the size of $3 a$

219 and one quarter the size of $2 \mathrm{a}$. Each cell has a single reticulated chloroplast with one

220 stalked pyrenoid. An eyespot comprising two rows of lipid globules is situated within a

221 chloroplast and belongs to type A. The nucleus is spherical and located posteriorly. Cysts

222 are proximate with a chasmic archeopyle.

223 HOLOTYPE: SEM stub of strain TIO278 designated as TIO201803 (illustrated in

224 Fig. 9) and deposited at Third Institute of Oceanography, State Oceanic Administration, 
225 Xiamen 361005, China.

226 TYPE LOCALITY: Arcachon Bay, France $\left(1^{\circ} 4^{\prime} 0.0^{\prime \prime} \mathrm{W}, 44^{\circ} 38^{\prime} 11.0^{\prime \prime} \mathrm{N}\right)$; Collection 227 date: 15 and 19-April 2016.

228 ETYMOLOGY: The epithet arcachonensis is named after the type locality, 229 Arcachon Bay.

$230 \quad$ HABITAT: Benthic sand-dwelling or epiphytic on seagrass.

DISTRIBUTION: Brackish and marine coastal water of French Atlantic (21.3-23

psu), North Sulawesi, Indonesia.

233

GENBANK ACCESSION NUMBER SEQUENCES: MK012071 (SSU rDNA),

MK012076 (LSU rDNA) and MK012081 (ITS rDNA) of strain TIO278.

235

236 Morphology

237 Cysts of Caladoa arcachonensis, isolated from Arcachon Bay, France surface sediment

238 samples are spherical or ovoid in shape, proximate and with a well-defined posteriorly

239 located cingulum (Fig. 1). They are 23.9-28.1 $\mu \mathrm{m}$ long $($ mean $=26.6 \pm 2.3 \mu \mathrm{m}, \mathrm{n}=3)$

240 and 19.9-24.4 $\mu \mathrm{m}$ wide $($ mean $=22.0 \pm 2.3 \mu \mathrm{m}, \mathrm{n}=3)$. Each cyst contains an endospore,

241 green to brown granules, a pyrenoid and the red eyespot. Two cysts were isolated, but

242 only one germinated, displaying a chasmic archeopyle on the epitheca (Fig. 2). The cyst

243 wall is transparent and it appears to be smooth (Fig. 3). Sometimes, small detrital

244 particles can be attached to the cyst wall surface. The germinated cell had a pronounced 
245 eyespot in the sulcal area (Fig. 4). The cysts withstand palynological treatment.

246 Cells of the French strain TIO278 are 16.7-23.5 $\mu \mathrm{m}$ long (mean $=19.8 \pm 2.2 \mu \mathrm{m}, \mathrm{n}$

$247=30)$ and $13.1-19.4 \mu \mathrm{m}$ wide $($ mean $=16.4 \pm 1.8 \mu \mathrm{m}, \mathrm{n}=30)$. The cells have a rounded

248 epitheca and hypotheca with a much larger epitheca (Fig. 5). There is a ring-like pyrenoid

249 located in the epicone and one pronounced orange eyespot in the sulcal area (Fig. 6).

250 There is a single chloroplast forming a network in the periphery of the cell ('c' in Fig. 7).

251 The nucleus is rounded and located posteriorly ('N' in Fig. 8).

252 The thecae have a plate formula of Po, cp, X, 4', 3a, 7", 6C, 5S, 5"', 2"'"' (Figs. 9-16).

253 The epitheca: hypotheca length ratio in the dorsal side is $1.5-1.8($ mean $=1.6 \pm 0.1, \mathrm{n}=$

254 7). Thecal pores with a diameter of $0.1-0.2 \mu \mathrm{m}$ are randomly scattered throughout the

255 thecal plates (Figs. 10, 11, 15). The epithecal plates are symmetrical in arrangement

256 (bipesoid). There are four apical plates. Plate 1' and 3' are six-sided and are nearly

257 symmetrical (Figs. 13, 14). Plate $2^{\prime}$ and $4^{\prime}$ are seven-sided and similar in size, much

258 larger than the other apical plates (Figs. 13, 14). There are three anterior intercalary plates

259 (1a, 2a and 3a), of which 1a and $3 \mathrm{a}$ are pentagonal and $2 \mathrm{a}$ is hexagonal. Plate 1a is about

260 half the size of $3 a$ and one quarter the size of $2 a$ (Fig. 14). There are seven precingular

261 plates among which the fourth is four-sided and smallest, whereas the others are

262 five-sided (Figs. 9, 10, 13, 14). The cingulum is $1.6-2.8 \mu \mathrm{m}$ wide (mean $=2.3 \pm 0.4 \mu \mathrm{m}$,

$263 \mathrm{n}=12$ ), situated in the low part of the cell and descended ca. half its width (Fig. 9). The

264 cingulum comprises six plates. The cingular plates are similar in size except $\mathrm{C} 1$ is

265 relatively smaller (Figs. 9, 10, 15). The apical pore complex is tear-shaped comprising a 
266 round pore plate $(\mathrm{Po})$, a round apical pore covered by a cover plate (cp) and an elongated

267 canal plate (X) (Figs. 13, 14). There are five postcingular plates, among them the third

268 and fifth postcingular plates $\left(3^{\prime \prime \prime}, 5^{\prime \prime \prime}\right)$ are five-sided whereas the other plates are

269 four-sided (Fig. 12). The antapical plates (1"'"', 2'"') are five-sided and similar in size (Fig.

$27012)$.

271 There are five sulcal plates. The large anterior sulcal plate (Sa) intrudes the epitheca

272 (Fig. 16). The left sulcal (Ss) is elongated and narrow. The median sulcal (Sm) is small

273 and always masked by the sulcal list emerging from the right sulcal plate (Sd). The

274 posterior sulcal plate ( $\mathrm{Sp}$ ) is seven-sided and has no contact with the cingulum (Figs. 15,

275 16). A peduncle was not observed. Schematic drawings showing the plate patterns of

276 Caladoa arcachonensis are provided in Figs. 17-20. Plate overlap (Figs. 19, 20) was

277 identified individually for each suture by inspecting cells with visible growth bands or by

278 internal theca views (Figs. 9-16). The third precingular and postcingular plates and the

279 fourth cingular plate were identified as the keystone plates (i.e., plates overlapping all

280 their neighbors).

281 Longitudinal sections through the cell of TIO278 show a large spherical nucleus in

282 the hypotheca, a stalked pyrenoid in the epitheca, a single chloroplast in the periphery

283 and an eyespot in the sulcal region (Figs. 21, 22). The nucleus consists of condensed

284 chromosomes with a smooth nuclear envelope. The chloroplast is enveloped by three

285 membranes and the thylakoids are grouped in threes to form lamellae (Fig. 23). The

286 stalked pyrenoid is surrounded by a starch sheath without intrusion of lamellae (Fig. 24). 
287 Many diamond-shaped trichocysts were observed beneath the thecate wall (Fig. 23). The

288 eyespot is located within a chloroplast comprising two rows of $\sim 20$ lipid globules in each

289 row (Figs. 25, 26). The lipid globules are $~ 100-150 \mathrm{~nm}$ in diameter. A microtubular

290

strand of the peduncle and a pusular system were not observed but an intensive search

291 was not carried out.

292 Cells of the Indonesian strain TIO339 are 13.2-18.9 $\mu \mathrm{m}$ long (mean $=16.5 \pm 1.5 \mu \mathrm{m}, \mathrm{n}$

$293=24)$ and $10.7-15.2 \mu \mathrm{m}$ wide $($ mean $=12.9 \pm 1.1 \mu \mathrm{m}, \mathrm{n}=29)$. The cells show a spherical

294 nucleus in the hypotheca, an orange eyespot in the sulcal region and a single reticulated

295 chloroplast with a doughnut-shaped pyrenoid in the epitheca (Figs. 27, 28). Cell

296 morphology of strain TIO339 is indistinguishable from strain TIO278 (Figs. 29-34).

\section{Molecular analysis and phylogeny}

The French strains TIO278 and TIO282 shared identical SSU, LSU and ITS rDNA sequences, and the Indonesian strains TIO339 and TIO340 shared identical SSU, LSU and ITS rDNA sequences as well. Strain TIO278 differed from TIO339 at 13 positions (SSU rDNA, 99.2\% similarity out of 1724 bp), 61 positions (LSU rDNA, 95.5\% similarity out of $1331 \mathrm{bp}$ ), and 131 positions (ITS rDNA, 79.8\% similarity out of $648 \mathrm{bp}$ ). The genetic distance based on ITS rDNA sequences was 0.17 between French and Indonesian strains.

305 The maximum likelihood (ML) and Bayesian inference (BI) analysis based on combined SSU rDNA and partial LSU rDNA sequences yielded similar phylogenetic 
307 trees. The BI tree was illustrated in Fig. 35. The order Peridiniales is well resolved (0.9

$308 \mathrm{BPP} / 55 \mathrm{BS}$ ) encompassing the families Peridiniaceae, Peridiniopsidaceae,

309 Thoracosphaeraceae, Kryptoperidiniaceae, and the genera Caladoa, Bysmatrum and

310 Vulcanodinium as well. The genus Caladoa was monophyletic with maximal support (1.0

311 BPP/100 BS), which formed a sister clade of Bysmatrum with maximal support. They

312 were closest to a well resolved clade (0.90 BPP/93 BS) formed by Peridiniaceae and

313 Vulcanodinium rugosum E. Nézan \& N. Chomérat with a low Bayesian posterior

314 probability $(<0.7 \mathrm{BPP})$ and moderate ML bootstrap support (58 BS).

315

316 Discussion

317 Morphology

318 To determinate plate homologies, the plate overlap pattern was investigated. Plate

319 overlap pattern of strain TIO278 (Figs. 19, 20) is generally consistent with other

320 dinoflagellates, following a trend from dorsal to ventral and from equatorial to poles

321 (Netzel \& Dürr, 1984). The third precingular plate is identified as the keystone plate in

322 our strain, also previously reported for Parvodinium marciniakii J. Kretschmann, P.

323 Owsianny, A.Z. Zerdoner \& M. Gottschling by Kretschmann et al. (2018) and

324 Parvodinium umbonatum (F. Stein) S. Carty by Luo et al. (2018). In contrast, the fourth

325 precingular plate was the keystone plate in many other species of Peridiniales including

326 Bysmatrum subsalsum (C.H. Ostenfeld) M.A. Faust \& K.A. Steidinger and 
327

328

329

330

331

332

333

334

335

336

337

338

339

340

341

342

343

344

345

346

347

Vulcanodinium rugosum (Luo et al., 2018), Scrippsiella acuminata (C.G. Ehrenberg) J.

Kretschmann, M. Elbrächter, C. Zinssmeister, S. Soehner, M. Kirsch, W.-H. Kusber \& M.

Gottschling (Kretschmann et al., 2015), Peridinium cinctum (Dürr, 1979),

Fusiperidinium wisconsinense (S. Eddy) F.M.G. McCarthy, H. Gu, K.N. Mertens \& C.

Carbonell-Moore (McCarthy et al., 2018), Heterocapsa triquetra (C.G. Ehrenberg) F.

Stein (Tillmann et al., 2017), Parvodinium travinskii J. Kretschmann, P. Owsianny, A.Z.

Zerdoner \& M. Gottschling, Parvodinium mixtum Wołoszyńska ex J. Kretschmann, P.

Owsianny, A.Z. Zerdoner \& M. Gottschling (Kretschmann et al., 2018) and Parvodinium

umbonatum (Elbrächter \& Meyer, 2001). In addition, Caladoa has a primtegulate series

that touches the terttegulate series, which can also be found in Scrippsiella Balech ex

A.R.Loeblich III, Fusiperidinium F.M.G. McCarthy, H. Gu, K.N. Mertens \& C.

Carbonell-Moore, Parvodinium, and Heterocapsa F. Stein, but is different from

Bysmatrum, Vulcanodinium, Peridinium and Protoperidinium, where both series are

separated (partly) by the sectegulate series.

The central ventral plate of strain TIO278 (denoted here by Sa) is overlapped by all

adjacent epithecal plates including the first apical plate $1^{\prime}$. This ventral plate is identified

as homologous with the anterior sulcal plate $(\mathrm{Sa})$ instead of a precingular plate because

plate $1^{\prime}$ is generally overlapped by precingular plates (Dürr \& Netzel, 1974; Fensome et

al., 1993). The plate pattern of strain TIO278 was thus determined as Po, cp, X, 4', 3a, 7",

$6 \mathrm{C}, 5 \mathrm{~S}, 5^{\prime \prime \prime}, 2^{\prime \prime \prime \prime}$. This plate formula is reminiscent of several previously described genera,

including the freshwater genera Chimonodinium S.C. Craveiro, A.J. Calado, N. 
348 Daugbjerg, Gert Hansen \& Ø. Moestrup and Fusiperidinium (Craveiro et al., 2011;

349 McCarthy et al., 2018), freshwater-brackish genus Apocalathium S.C. Craveiro, N.

350 Daugbjerg, Ø. Moestrup \& A.J. Calado (Craveiro et al., 2016), and brackish-marine

351 genera Bysmatrum, Scrippsiella and Vulcanodinium (Nézan \& Chomérat, 2011; Luo et

352 al., 2016; Luo et al., 2018). The strain TIO278 can be separated from these genera

353 primarily based on the size and location of Sa plate, which is large and intrudes deeply in

354 the epitheca. Such kind of Sa plate was only reported in marine Heterocapsa (Tillmann et

355 al., 2017) and Laciniporus Saburova \& N. Chomérat (Saburova \& Chomérat 2018),

356 freshwater Parvodinium (Carty, 2008) and Palatinus S. Craveiro, A. Calado, N.

357 Daugbjerg \& Ø. Moestrup (Craveiro et al., 2009). A similar plate was observed in

358 Sphaerodinium cracoviense J. Wołoszyńska (Craveiro et al., 2010), but the authors

359 expressed some doubts whether it should be considered as a Sa plate. Interestingly, such a

360 type of deeply intruding Sa with similar overlap with the $1^{\prime}$ has also been recorded for the

361 fossil cyst Susadinium? pinna (Below) Lentin \& Williams by Below (1987, as Dodekovia

362 pinna Below) described from the Lower Jurassic (Toarcian), a species assigned to the

363 Heterocapsaceae (Fensome et al., 1993); this suggests that this type of Sa is a primitive

364 evolutionary trait, not present in genera that have presumably evolved later, such as

365 Protoperidinium.

368 Strain TIO278 differs from Chimonodinium in the presence of a pyrenoid and lack of a 
369 peduncle (Craveiro et al., 2011), from Scrippsiella in the size of the first cingular plate

370 (Luo et al., 2016) and it differs from Fusiperidinium, Apocalathium and Vulcanodinium

371 in the presence of an eyespot (Nézan \& Chomérat, 2011; Craveiro et al., 2016; McCarthy

372 et al., 2018), as well as it differs from Bysmatrum in the configuration of anterior

373 intercalary plates. Plates $2 \mathrm{a}$ and $3 \mathrm{a}$ are separated in Bysmatrum, but they touch in strain

374 TIO278. Strain TIO278 shares a similar Sa plate with Heterocapsa and Laciniporus, but

375 it differs in the plate pattern. Only two anterior intercalary plates are present in

376 Heterocapsa and Laciniporus and an eyespot is not observed (Tillmann et al., 2017,

377 Saburova \& Chomérat 2018). Strain TIO278 shares a type A eyespot with Peridinium but

378 differs in the number of cingular plates (six versus five), therefore, a new genus Caladoa

379 is established to incorporate TIO278 and related strains.

380 Caladoa arcachonensis is morphologically close to the freshwater "Peridinium

381 subtatranum" (invalidly described), Apocalathium aciculiferum var. inerme (J.

382 Wołoszyńska) Ø. Moestrup \& A.J. Calado and Chimonodinium lomnickii var. minus (J.

383 Wołoszyńska) Ø. Moestrup based on the plate pattern and a large Sa plate, but it differs

384 in the relative size of anterior intercalary plates and the size of the apical pore

385 (Wołoszyńska, 1916, Wołoszyńska, 1937, Wołoszyńska, 1952, Moestrup \& Calado,

386 2018). Caladoa arcachonensis is also morphologically close to Chimonodinium lomnickii

387 (J. Wołoszyńska) S.C. Craveiro, A.J. Calado, N. Daugbjerg, Gert Hansen \& Ø. Moestrup

388 and Chimonodinium lomnickii var. wierzejskii (J. Wołoszyńska) S.C. Craveiro, A.J.

389 Calado, N. Daugbjerg, Gert Hansen \& Ø. Moestrup but differs in the size and location of 
390 the Sa and relative size of anterior intercalary plates (Craveiro et al., 2011, Moestrup \&

391 Calado, 2018). Caladoa arcachonensis differs from Peridinium gutwinskiiJ.

392 Wołoszyńska and Peridinium bipes F. Stein in the number of cingular plates and

393 relative size of anterior intercalary plates (Boltovskoy, 1989; Lee et al., 2006), and differs

394 from Peridinium allorgei M. Lefèvre in the cell shape and relative size of anterior

395 intercalary plates (Moestrup \& Calado 2018). Caladoa arcachonensis differs from

396 Apocalathium malmogiense (G. Sjöstedt) S.C. Craveiro, N. Daugbjerg, Ø. Moestrup \&

397 A.J. Calado in a much larger epitheca and relative size of anterior intercalary plates

398 (Craveiro et al., 2016).

$399 \quad$ Phylogeny and genetic differentiation

400 The only morphological difference between French strain TIO278 and Indonesian strain

401 TIO339 is the cell size, therefore, they are considered to be the same morphospecies.

402 These strains however inhabit temperate and tropical waters, respectively, and are likely

403 to differ in their eco-physiological traits. These two strains also have a genetic distance,

404 based on ITS sequences, as much as 0.17 , and that is much larger than the threshold value

405 (0.04) for differentiating dinoflagellate species at interspecific level (Litaker et al., 2007),

406 therefore suggesting the existence of cryptic species. The French strain has a cyst stage,

407 but whether the Indonesian strain produces cysts is yet to be determined.

408 Our molecular phylogeny supports the classification of Caladoa within the order

409 Peridiniales, consistent with the morphological features characteristic of Peridiniales,

410 such as a symmetrical $1^{\prime}$ plate and two symmetrical antapical plates. The close 
411 relationship between Caladoa and Bysmatrum, however, is surprising. Bysmatrum shows

412 an asymmetrical 1' plate and two somewhat asymmetrical antapical plates that even do

413 not fit to the definition of Peridiniales (Fensome et al., 1993). However, Bysmatrum and

414 Caladoa share identical plate pattern and most importantly, they share a type A eyespot 415 (located within the chloroplast and consisted of several two rows of opaque globules)

416 (Moestrup \& Daugbjerg, 2007; Dawut et al., 2018). A type A eyespot appears to be a 417 common feature of Peridiniales, reported also in Scrippsiella acuminata and 418 Chimonodinium lomnickii (Craveiro et al., 2011), Palatinus apiculatus (C.G. Ehrenberg) 419 S. Craveiro, A. Calado, N. Daugbjerg \& Ø. Moestrup (Craveiro et al., 2009), Naiadinium 420 polonicum (J. Wołoszyńska) S. Carty (Craveiro et al., 2015), and Peridinium willei H. 421 Huitfeldt-Kaas (Moestrup \& Daugbjerg, 2007). Bysmatrum can also have a type B 422 eyespot but this is a modified type A eyespot, with the difference only in the presence of 423 an overlying brick like crystals (Luo et al., 2018). Caladoa and Bysmatrum both have 424 proximate cysts that are similar to the motile cells (Anglès et al., 2017; Luo et al., 2018). 425 A new family is possible for Caladoa and Bysmatrum in view of their morphological 426 similarity, but evidence from more closely related species is needed.

427 The close relationship between Vulcanodinium and Peridinium sensu stricto has been 428 reported before based on the LSU rDNA sequences (Nézan \& Chomérat, 2011), 429 concatenated data from SSU, ITS and LSU rDNA sequences (Luo et al., 2018), and 430 supported here again based on concatenated data from SSU and LSU rDNA sequences. It 431 is worth noting that the closest relative of Peridinium is a brackish species, in contrast 
432 with the suggestion that marine and freshwater species are usually not closely related 433 (Logares et al., 2007). However, Vulcanodinium has six cingular plates compared to five 434 in Peridinium sensu stricto (Boltovskoy, 1975; Nézan \& Chomérat, 2011), and 435 Vulcanodinium does not have a type A eyespot whereas Peridinium cinctum and P. willei 436 have one (Spector \& Triemer, 1979; Moestrup \& Daugbjerg, 2007). The assignment of 437 Vulcanodinium to Peridiniaceae is possible depending on the emendation of Peridiniaceae.

438 Multi-gene phylogenies or phylotranscriptomics should provide more evidence for a 439 definite assignment.

440

\section{Acknowledgements}

442 We thank two anonymous reviewers for constructive suggestions that improved the

443 manuscript greatly. Claire Meteigner and Myriam Rumèbe are acknowledged for

444 collecting samples from Arcachon Bay.

$445 \quad$ Funding

446 This work was supported by the National Key Research and Development Program of

447 China (2016YFE0202100), National Natural Science Foundation of China (41676117, 448 41806154), and China-ASEAN Maritime Cooperation Fund.

\section{Author contributions}

451 Z. Luo: light microscopy, electron microscopy and drafting manuscript; K.N. Mertens:

452 original concept, drafting and editing manuscript, incubation experiment, light 
453 microscopy; E. Nézan: drafting and editing manuscript; Li Gu: electron microscopy; Vera

454 Pospelova: palynological treatment, drafting and editing manuscript; H. Thoha: sampling

455 and editing manuscript; $\mathrm{H}$. Gu: original concept and editing of manuscript.

456

457 References

458 ADACHI, M., SAKO, Y. \& ISHIDA, Y. (1996). Analysis of Alexandrium (Dinophyceae)

459

460 species using sequences of the 5.8S ribosomal DNA and internal transcribed spacer regions. Journal of Phycology, 32: 424-432.

Anglès, S., ReÑÉ, A., GArcés, E., Lugliè, A., Sechi, N., CAMP, J. \& SATtA, C.T. (2017). Morphological and molecular characterization of Bysmatrum subsalsum (Dinophyceae) from the western Mediterranean Sea reveals the existence of cryptic species. Journal of Phycology, 53: 833-847.

BALECH, E. (1980). On the thecal morphology of dinoflagellates with special emphasis on circular and sulcal plates. Anales del Centro de Ciencias del Mar y Limnologia, Universidad Nacional Autonomia de Mexico, 7: 57-68.

BELOw, R. (1987). Evolution und Systematik von Dinoflagellaten-Zysten aus der Ordnung Peridiniales. I. Allgemeine Grundlagen und Subfamilie Rhaetogonyaulacoideae (Familie Peridiniaceae). Palaeontographica Abteilung B, 205: $1-164$.

472 Boc, A., Diallo, A.B. \& Makarenkov, V. (2012). T-REX: a web server for inferring, 473 validating and visualizing phylogenetic trees and networks. Nucleic Acids 
$474 \quad$ Research, 40: W573-W579.

475 Boltovskoy, A. (1975). Peridinium cinctum (Müller) Ehrenberg. Physis secc. B, 34: $476 \quad 73-84$.

477 Boltovskoy, A. (1989). Thecal morphology of the dinoflagellate Peridinium gutwinskii. $478 \quad$ Nova Hedwigia, 49: 369-380.

479 CARTY, S. (2008). Parvodinium gen. nov. for the Umbonatum group of Peridinium 480 (Dinophyceae). Ohio Journal of Science, 108: 103-107.

Craveiro, S., Calado, A.J., Daugbjerg, N. \& Moestrup, Ø. (2009). Ultrastructure and LSU rDNA-based revision of Peridinium group palatinum (Dinophyceae) with the description of Palatinus gen. nov. Journal of Phycology, 45: 1175-1194. Eukaryotic Microbiology, 57: 568-585. and large subunit rDNA-based phylogeny of Sphaerodinium cracoviense, an unusual freshwater dinoflagellate with a novel type of eyespot. Journal of

Craveiro, S.C., Calado, A.J., Daugbjerg, N., Hansen, G. \& Moestrup, Ø. (2011). Ultrastructure and LSU rDNA-based phylogeny of Peridinium lomnickii and description of Chimonodinium gen. nov. (Dinophyceae). Protist, 162: 590-615. Protistology, 51: 259-279. 
495 Craveiro, S.C., Daugbjerg, N., Moestrup, Ø. \& Calado, A.J. (2016). Studies on

496

497

498

499

500

501

502

503

504

505

506

507

508

509

510

511

512

513

514

515

Peridinium aciculiferum and Peridinium malmogiense (= Scrippsiella hangoei):

comparison with Chimonodinium lomnickii and description of Apocalathium gen.

nov. (Dinophyceae). Phycologia, 56: 21-35.

Daugbjerg, N., Hansen, G., Larsen, J. \& Moestrup, Ø. (2000). Phylogeny of some of the major genera of dinoflagellates based on ultrastructure and partial LSU rDNA sequence data, including the erection of three new genera of unarmoured dinoflagellates. Phycologia, 39: 302-317.

DawUT, M., Sym, S.D., SUdA, S. \& HORIGUCHI, T. (2018). Bysmatrum austrafrum sp. nov. (Dinophyceae), a novel tidal pool dinoflagellate from South Africa. Phycologia, 57: 169-178.

DÜRR, G. \& NETZEL, H. (1974). The fine structure of the cell surface in Gonyaulax polyedra (Dinoflagellata). Cell and Tissue Research, 150: 21-41.

DÜRR, G. (1979). Elektronenmikroskopische Untersuchungen am Panzer von Dinoflagellaten: II. Peridinium cinctum. Archiv für Protistenkunde, 122: 88-120.

ElbRÄCHTER, M. \& MEYER, B. (2001). Plate pattern variability and plate overlap in a clonal culture of the freshwater dinoflagellate Peridinium umbonatum Stein species complex (Dinophyceae). Neues Jahrbuch für Geologie und Paläontologie/Abhandlungen, 219: 221-227. 
516

517

518

519

520

521

522

523

524

525

526

527

528

529

530

531

532

533

534

535

536

Lewis, J., Meier, S.K.J., Montresor, M., Streng, M. \& Versteegh, G.J.M.

(2008). Establishing an agenda for calcareous dinoflagellate research

(Thoracosphaeraceae, Dinophyceae) including a nomenclatural synopsis of generic names. Taxon, 57: 1289-1303.

Fensome, R.A., TAYlor, F.J.R., NorRis, G., SARJeAnt, W.A.S., Wharton, D.I. \& WiLliAMS, G.L. (1993). A classification of fossil and living dinoflagellates. Micropaleontology Special Publication, 7: 1-245.

Gottschling, M., Soehner, S., Zinssmeister, C., John, U., Plötner, J., Schweikert, M., Aligizaki, K. \& ElBRÄCHTER, M. (2012). Delimitation of the Thoracosphaeraceae (Dinophyceae), including the calcareous dinoflagellates, based on large amounts of Ribosomal RNA sequence data. Protist, 163: 15-24.

Gottschling, M., Kretschmann, J. \& ČAlasan, A.Ž. (2017). Description of Peridiniopsidaceae, fam. nov. (Peridiniales, Dinophyceae). Phytotaxa, 299: 293-296.

Gu, H., LiU, T. \& MERTENS, K. (2015). Cyst-theca relationship and phylogenetic positions of Protoperidinium (Peridiniales, Dinophyceae) species of the sections Conica and Tabulata, with description of Protoperidinium shanghaiense sp. nov. Phycologia, 54: 49-66.

GuILLARD, R.R.L. \& RYTHER, J.H. (1962). Studies of marine planktonic diatoms. I. Cyclotella nana Hustedt and Detonula confervacea Cleve. Canadian Journal of Microbiology, 8: 229-239. 
537 HALL, T.A. (1999). BioEdit: a user-friendly biological sequence alignment editor and 538 analysis program for Windows 95/98/NT. pp. 95-98.

539 HEAD, M.J. (1996). Modern dinoflagellate cysts and their biological affinities. In 540 Palynology: principles and applications (Jansonius, J. \&McGregor, D.C., editors), 1197-1248. American Association of Stratigraphic Palynologists Foundation, Dallas.

HoriguCHI, T. \& TAKANO, Y. (2006). Serial replacement of a diatom endosymbiont in the marine dinoflagellate Peridinium quinquecorne (Peridiniales, Dinophyceae). Phycological Research, 54: 193-200.

546 KATOH, K. \& StANDLEY, D.M. (2013). MAFFT multiple sequence alignment software version 7: improvements in performance and usability. Molecular Biology and Evolution, 30: 772-780.

Kretschmann, J., Elbrächter, M., Zinssmeister, C., Soehner, S., Kirsch, M., Kusber, W.-H. \& GotTschling, M. (2015). Taxonomic clarification of the phylogenetics of dinophytes harboring diatoms as endosymbionts dinophyte Peridinium acuminatum Ehrenb., $\equiv$ Scrippsiella acuminata, comb. nov. (Thoracosphaeraceae, Peridiniales). Phytotaxa, 220: 239-256. Evolution, 118: 392-402. 
558 LEE, J.-J., JANG, S.-H., LEE, J.-H. \& LEE, J.-H. (2006). Morphology and ecology of

559 Peridinium bipes var. occultatum Lindem.(Dinophyceae) forming freshwater red tides in Korean dam reservoirs. Algae, 21: 433-443.

561 Lindberg, K., Moestrup, Ø. \& DaugbJerg, N. (2005). Studies on woloszynskioid 562 nov. and Jadwigia gen. nov. (Tovelliaceae fam. nov.). Phycologia, 44: 416-440.

LitaKer, W.R., VAndersea, M.W., Kibler, S.R., ReECE, K.S., StOKes, N.A., Lutzoni, Phycology, 43: 344-355.

F.M., Yonish, B.A., West, M.A., Black, M.N.D. \& Tester, P.A. (2007).

Recognizing dinoflagellate species using ITS rDNA sequences. Journal of

Logares, R., Shalchian-Tabrizi, K., Boltovskoy, A. \& Rengefors, K. (2007).

Extensive dinoflagellate phylogenies indicate infrequent marine-freshwater transitions. Molecular Phylogenetics and Evolution, 45: 887-903.

Luo, Z., Mertens, K.N., Bagheri, S., Aydin, H., Takano, Y., Matsuoka, K., MCCARTHY, F. MG \& GU, H. (2016). Cyst-theca relationship and phylogenetic positions of Scrippsiella plana sp. nov. and S. spinifera (Peridiniales, Dinophyceae). European Journal of Phycology, 51: 188-202.

Luo, Z., Lim, Z.F., Mertens, K.N., Gurdebeke, P., Bogus, K., Carbonell-Moore, C., Vrielinck, H., LeAw, C.P., Lim, P.T., ChOmÉRAt, N., Li, X. \& GU, H. (2018). Morpho-molecular diversity and phylogenetic relationship of Bysmatrum species 
579

580

581

582

583

584

585

586

587

588

589

590

591

592

593

594

595

596

597

598

599

(Dinophyceae) from the South China Sea and France. European Journal of Phycology, 53: 318-335.

McCarthy, F.M., Gu, H., Mertens, K.N., Carbonell-Moore, C., Krueger, A.M., TAKANO, Y. \& MATSUOKA, K. (2018). Transferring the freshwater dinoflagellate Peridinium wisconsinense (Dinophyceae) to the family Thoracosphaeraceae, with the description of Fusiperidinium gen. nov.. Phycological Research, 66: 137-168.

Medlin, L., Elwood, H.J., Stickel, S. \& Sogin, M.L. (1988). The characterization of enzymatically amplified eukaryotic 16S-like rRNA-coding regions. Gene, 71: 491-499.

Moestrup, Ø. \& DAUGBJERG, N. (2007). On dinoflagellate phylogeny and classification, in: Brodie, J. et al. (Ed.) (2007). Unravelling the algae: the past, present, and future of algal systematics. The Systematics Association Special Volume Series, 75: $215-230$.

Moestrup, Ø., LindBerg, K. \& DAugBJERG, N. (2009). Studies on woloszynskioid dinoflagellates IV: The genus Biecheleria gen. nov.. Phycological Research, 57: $203-220$.

Moestrup, Ø. \& CAlado, A.J. (2018). Dinophyceae. In Freshwater Flora of Central Europe (Büdel, B., Gärtner, G., Krienitz, L. \& Schagerl, M., editors), 6: 1-560, Springer, Berlin.

NÉZAN, E. \& CHOMÉRAT, N. (2011). Vulcanodinium rugosum gen. et sp. nov. (Dinophyceae), un nouveau dinoflagellé marin de la côte méditerranéenne 
600

601

602

603

604

605

606

607

608

609

610

611

612

613

614

615

616

617

618

619

620

française. Cryptogamie-Algologie, 32: 3-18.

Netzel, H. \& DÜRR, G. (1984). Dinoflagellate cell cortex. In Dinoflagellates (Spector, D.L., editor), Academic Press Inc., Orlando, Florida, 43-105.

PosADA, D. 2008. jModelTest: phylogenetic model averaging. Molecular Biology and Evolution, 25: 1253-1256.

PIENAAR, R.N., SAKAI, H. \& HoriguCHI, T. (2007). Description of a new dinoflagellate with a diatom endosymbiont, Durinskia capensis sp. nov. (Peridiniales, Dinophyceae) from South Africa. Journal of Plant Research, 120: 247-258.

RONQuist, F. \& HuELSENBECK, J.P. (2003). MrBayes 3: Bayesian phylogenetic inference under mixed models. Bioinformatics, 19: 1572-1574.

Saburova, M., Chomérat, N. \& Hoppenrath, M. (2012). Morphology and SSU rDNA phylogeny of Durinskia agilis (Kofoid \& Swezy) comb. nov. (Peridiniales, Dinophyceae), a thecate, marine, sand-dwelling dinoflagellate formerly classified within Gymnodinium. Phycologia, 51: 287-302.

SABURova M. \& CHOMÉRAT, N. (2018). Laciniporus arabicus gen. et sp. nov.(Dinophyceae, Peridiniales), a new thecate, marine, sand-dwelling dinoflagellate from the northern Indian Ocean (Arabian Sea). Journal of Phycology, doi: 10.1111/jpy.12783.

Scholin, C.A., Herzog, M., Sogin, M. \& Anderson, D.M. (1994). Identification of group- and strain-specific genetic markers for globally distributed Alexandrium (Dinophyceae). II. Sequence analysis of a fragment of the LSU rRNA gene. 
621

622

623

624

625

626

627

628

629

630

631

632

633

634

635

636

637

638

639

640

641

Journal of Phycology, 30: 999-1011.

SPECtOR, D. \& TRIEMER, R. (1979). Ultrastructure of the dinoflagellate Peridinium

cinctum f. ovoplanum. I. Vegetative cell ultrastructure. American Journal of Botany, 66: 845-850.

SPURR, A.R. (1969). A low-viscosity epoxy resin embedding medium for electron microscopy. Journal of Ultrastructure Research, 26: 31-43.

STAMATAKIS, A. (2006). RAxML-VI-HPC: maximum likelihood-based phylogenetic analyses with thousands of taxa and mixed models. Bioinformatics, 22: $2688-2690$.

SWOFFORD, D. (2002). Sinauer Associates; Sunderland, MA: 2002PAUP*. Phylogenetic analysis using parsimony (* and other methods), version $4 \mathrm{~b} 10$.

TAMURA, M., SHIMWIA, S. \& HoriguCKI, T. (2005). Galeidinium rugatum gen. et sp. nov. (Dinophyceae), a new coccoid dinoflagellate with a diatom endosymbiont. Journal of Phycology, 41: 658-671.

Tillmann, U., Hoppenrath, M., Gottschling, M., Kusber, W.-H. \& Elbrächter, M. (2017). Plate pattern clarification of the marine dinophyte Heterocapsa triquetra sensu Stein (Dinophyceae) collected at the Kiel Fjord (Germany). Journal of Phycology, 53: 1305-1324.

Wołoszyńska, J. (1916). Polskie Peridineae słodkowodne. - Polnische Süsswasser -Peridineen. Bulletin International de l'Academie des Sciences de Cracovie, Classe des Sciences Mathématiques et Naturelles, série B: Sciences Naturelles, 
642

643

644

645

646

647

648

649

650

651

652

653

654

655

656

657

658

659

660

661

662

1915: 260-285.

WoŁoszyŃSKA, J. (1937). Die Algen der Tatraseen und Tümpel. III. Peridineen im

Winterplankton einiger Tatraseen. Archiwum Hydrobiologji i Rybactwa, 10:

188-196

WoŁOSZYŃSKA, J. (1952). Bruzdnice Tatr i Karpat Wschodnich [Peridineae montium

Tatrensium et Carpathorum Orientalium]. Acta Societatis Botanicorum Poloniae,

21: 311-316.

YAMADA, N., SYM, S.D. \& HoRIGUCHI, T. (2017). Identification of highly divergent

diatom-derived chloroplasts in dinoflagellates, including a description of

Durinskia kwazulunatalensis sp. nov. (Peridiniales, Dinophyceae). Molecular

Biology and Evolution, 34: 1335-1351.

You, X., LuO, Z., Su, Y., Gu, L. \& Gu, H. (2015). Peridiniopsis jiulongensis, a new

freshwater dinoflagellate with a diatom endosymbiont from China. Nova

Hedwigia, 100: 313-326.

\section{Figure captions}

Figs. 1-4. Light micrographs of cysts and cells of Caladoa arcachonensis from France.

Fig. 1. Ventral view showing the outline and a post-equatorial cingulum of a living cyst with a pyrenoid (p) and eyespot (arrow). Fig. 2. The cyst in Fig. 1 upon germination showing the chasmic archeopyle (arrow). Fig. 3. The cyst in Fig. 1 upon germination showing granular surface. Fig. 4. Ventral view of the germinated 
663

664 665

666

667

668

669

670

671

672

673

674

675

676

677

678

679

680

681

682

683

cell from the cyst in Fig. 1, showing a red eyespot in the sulcal area (e). Scale bars $=5 \mu \mathrm{m}$.

Figs. 5-8. Light micrographs of cells of Caladoa arcachonensis strain TIO278 from France. Fig. 5. Ventral view showing a rounded epitheca and hypotheca with a post-equatorial cingulum. Fig. 6. Lateral view showing a ring like pyrenoid (p) and a red eyespot (arrow). Fig.7. Epifluorescence image of a cell in ventral view showing the single reticulate chloroplast (c) in the periphery of the cell. Fig. 8. Epifluorescence image of a SYBR Green-stained cell showing a spherical nucleus (N). Scale bars $=5 \mu \mathrm{m}$.

Figs. 9-12. Scanning electron micrographs of vegetative cells of Caladoa arcachonensis strain TIO278 from France. Fig. 9. Ventral view showing the first apical plate (1'), anterior sulcal plate $(\mathrm{Sa})$, right sulcal plate $(\mathrm{Sd})$, posterior sulcal plate $(\mathrm{Sp})$, and the first three cingular plates $(\mathrm{C} 1-\mathrm{C} 3)$. Fig. 10. Dorsal view showing three anterior intercalary plates $(1 \mathrm{a}-3 \mathrm{a})$, three precingular plates $\left(3^{\prime \prime}-5^{\prime \prime}\right)$, three cingular plates (C3 - C5) and two postcingular plates $\left(3^{\prime \prime \prime}, 4^{\prime \prime \prime}\right)$. Fig. 11. Ventral-lateral right view showing two precingular plates $\left(6^{\prime \prime}, 7^{\prime \prime}\right)$, sixth cingular plate (C6) and fifth postcingular plate $\left(5^{\prime \prime \prime}\right)$. Fig. 12. Dorso-antapical view showing five postcingular plates $\left(1^{\prime \prime \prime}-5^{\prime \prime \prime}\right)$ and two antapical plates $\left(1^{\prime \prime \prime \prime}, 2^{\prime \prime \prime \prime}\right)$ of similar size. Scale bars $=5$ $\mu \mathrm{m}$. 
684

685

686

687

688

689

690

691

692

693

694

695

696

697

698

699

700

701

702

703

704

Figs. 13-16. Scanning electron micrographs of vegetative cells of Caladoa

arcachonensis strain TIO278 from France. Fig. 13. Ventro-apical view showing four apical plates $\left(1^{\prime}-4^{\prime}\right)$, the anterior sulcal plate $(\mathrm{Sa})$, the first anterior intercalary plate (1a) and three precingular plates (1", 2", 7"). Fig. 14. Dorso-apical view showing three apical plates $\left(2^{\prime}-4^{\prime}\right)$, three anterior intercalary plates $(1 \mathrm{a}-3 \mathrm{a})$ and five precingular plates $\left(2^{\prime \prime}-6^{\prime \prime}\right)$. Fig. 15. Internal view of the hypotheca showing six cingular plates $(\mathrm{C} 1-\mathrm{C} 6)$ and right sulcal plate $(\mathrm{Sd})$, left sulcal plate $(\mathrm{Ss})$, median sulcal plate $(\mathrm{Sm})$ and posterior sulcal plate $(\mathrm{Sp})$. Fig. 16. Sulcal area showing the first cingular plate (C1) and plates $\mathrm{Sa}, \mathrm{Sd}, \mathrm{Sp}$ and $\mathrm{Ss}$ (arrow). Scale bars $=5 \mu \mathrm{m}$

Figs. 17-20. Schematic drawings of thecal plate patterns of Caladoa arcachonensis. Fig. 17. Ventral view. Fig. 18. Dorsal view. Fig. 19. Apical view showing plate overlap patterns. Fig. 20. Antapical view showing plate overlap patterns.

Figs. 21-26. Transmission electron micrographs of vegetative cells of Caladoa arcachonensis strain TIO278 from France. Figs. 21, 22. Longitudinal sections through the cell showing a large nucleus $(\mathrm{N})$, a stalked pyrenoid (p), a single chloroplast (c) in the periphery of the cell and an eyespot (arrow). Fig. 23. The chloroplast showing the thylakoids grouped in threes to form lamellae and several 
705

706

707

708

709

710

711

712

713

714

715

716

717

718

719

720

721

722

723

724

725

trichocysts (arrow). Fig. 24. Detail of the stalked pyrenoid (p) with dense matrices

and a surrounding starch (s). Figs. 25, 26. The eyespot (e) located within a

chloroplast (c) comprising two rows of globular lipids. Scale: Figs. $21,22=5 \mu \mathrm{m}$,

Figs. $23-26=1 \mu \mathrm{m}$.

Figs. 27-28. Light micrographs of vegetative cells of Caladoa arcachonensis strain

TIO339 from Indonesia. Fig. 27. Lateral view of a living cell showing a pyrenoid

(p), a nucleus $(\mathrm{N})$ and an eyespot (arrow). Fig. 28. Dorwal view of a living cell showing a single chloroplast forming a network. Scale bars $=5 \mu \mathrm{m}$.

Figs. 29-34. Scanning electron micrographs of vegetative cells of Caladoa arcachonensis strain TIO339 from Indonesia. Fig. 29. Ventro-antapical view showing the anterior sulcal plate $(\mathrm{Sa})$, the right sulcal plate $(\mathrm{Sd})$, posterior sulcal plate $(\mathrm{Sp})$, two postcingular plates $\left(1^{\prime \prime \prime}, 5^{\prime \prime \prime}\right)$ and two antapical plates $\left(1^{\prime \prime \prime \prime}, 2^{\prime \prime \prime \prime}\right)$. Fig.

30. Dorsal view showing three precingular plates $\left(4^{\prime \prime}-6^{\prime \prime}\right)$, three cingular plates $(\mathrm{C} 4-\mathrm{C} 6)$ and three postcingular plates $\left(3^{\prime \prime \prime}-5^{\prime \prime \prime}\right)$. Fig. 31. Dorso-apical view showing four precingular plates $\left(2^{\prime \prime}-5^{\prime \prime}\right)$, three anterior intercalary plates $(1 \mathrm{a}-3 \mathrm{a})$.

Fig. 32. Antapical view showing four postcingular plates $\left(2^{\prime \prime \prime}-5^{\prime \prime \prime}\right)$, plate Sp and two antapical plates $\left(1^{\prime \prime \prime \prime}, 2^{\prime \prime \prime \prime}\right)$ of similar size. Fig. 33. Internal view of the hypotheca showing six cingular plates $(\mathrm{C} 1-\mathrm{C} 6)$. Fig. 34. The sulcus showing Sa, $\mathrm{Sd}, \mathrm{Sp}$ and left sulcal plate (arrow). Scale bars $=5 \mu \mathrm{m}$. 
727 Fig. 35. Phylogeny of Caladoa inferred from concatenated SSU and partial LSU rDNA

728 sequences using maximum likelihood (ML). New sequences are indicated in bold.

729 Branch lengths are drawn to scale, with the scale bar indicating the number of

730 nucleotide substitutions per site. Numbers on branches are statistical support values

731 to clusters on the right of them (left: ML bootstrap support (BS) values; right:

732 Bayesian posterior probabilities (BPP). Bootstrap support values $>50 \%$ and

733 Bayesian posterior probabilities above 0.7 are shown. Asterisk indicates maximal

$734 \quad$ support $(\mathrm{ML} \mathrm{BS}=100 \%$ and $\mathrm{BPP}=1.00)$. 
Table 1 Strains of Caladoa arcachonensis examined in the present study, including collection data, locations and sources

\begin{tabular}{|c|c|c|c|c|c|c|}
\hline Species & Strains & Longitude & Latitude & Collectiton date & Sources & Collection locality \\
\hline Caladoa arcachonensis & $\begin{array}{l}\text { TIO278, } \\
\text { TIO282 }\end{array}$ & $1^{\circ} 4^{\prime} 0.0^{\prime \prime} \mathrm{W}$ & $44^{\circ} 38^{\prime} 11.0^{\prime \prime} \mathrm{N}$ & $\begin{array}{l}15 \text { and } 19 \text { April } \\
2016\end{array}$ & Sediment & Arcachon Bay, France \\
\hline Caladoa arcachonensis & TIO339 & $124^{\circ} 51^{\prime} 6.4^{\prime \prime} \mathrm{E}$ & $1^{\circ} 35^{\prime} 44.8^{\prime \prime} \mathrm{N}$ & 2016.07.31 & Seagrass & Manado, Indonesia \\
\hline Caladoa arcachonensis & TIO340 & $125^{\circ} 13 ' 38.6^{\prime \prime} \mathrm{E}$ & $1^{\circ} 32^{\prime} 3.7^{\prime \prime} \mathrm{N}$ & 2016.08 .01 & Coral sands & Bitung, Indonesia \\
\hline
\end{tabular}



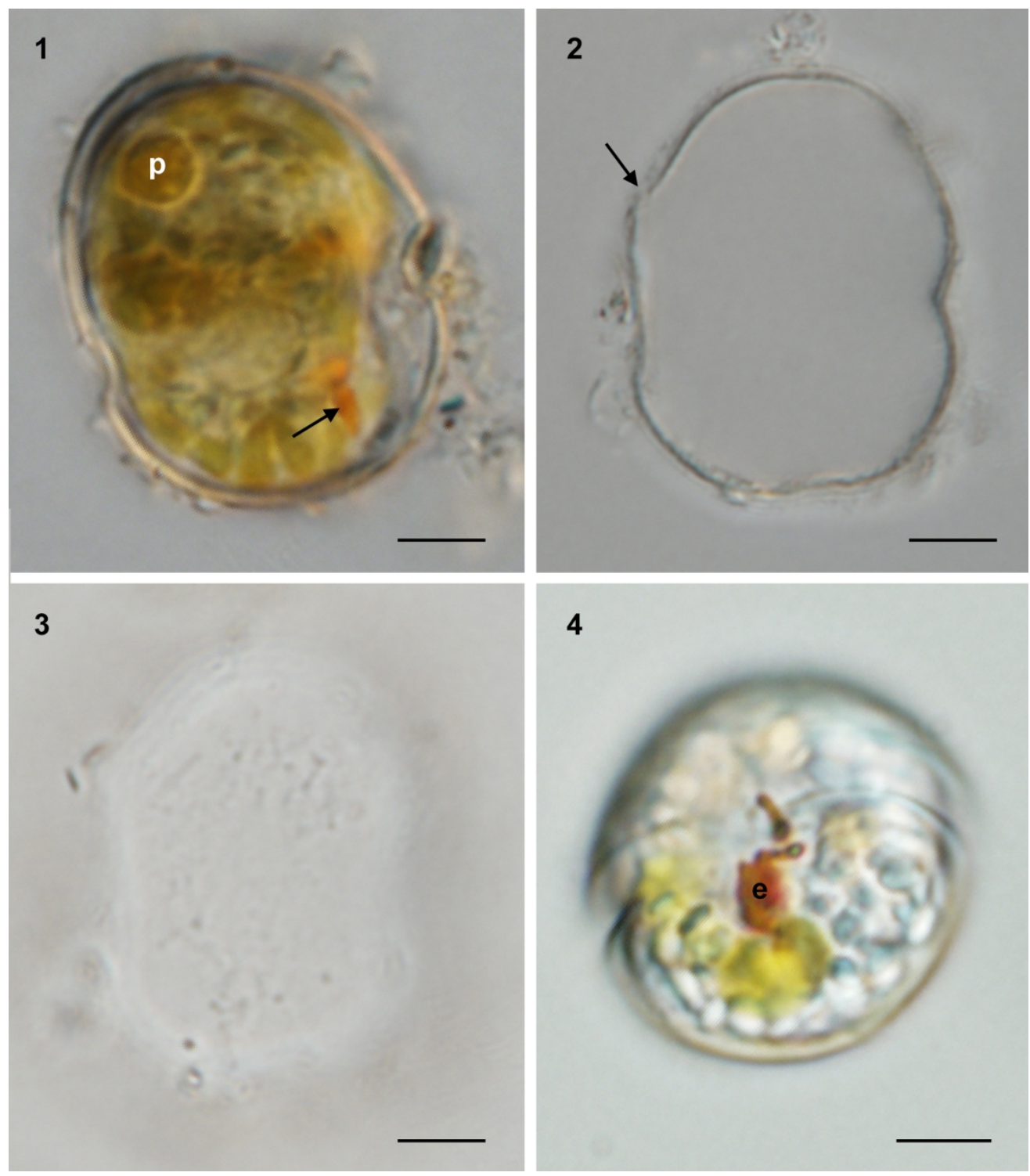

Figs. 1-4. Light micrographs of cysts and cells of Caladoa arcachonensis from France. Fig. 1. Ventral view showing the outline and a post-equatorial cingulum of a living cyst with a pyrenoid (p) and eyespot (arrow). Fig. 2. The cyst in Fig. 1 upon germination showing the chasmic archeopyle (arrow). Fig. 3. The cyst in Fig. 1 upon germination showing granular surface. Fig. 4. Ventral view of the germinated cell from the cyst in Fig. 1, showing a red eyespot in the sulcal area (e). Scale bars $=5 \mu \mathrm{m}$.

\section{$170 \times 193 \mathrm{~mm}(300 \times 300 \mathrm{DPI})$}



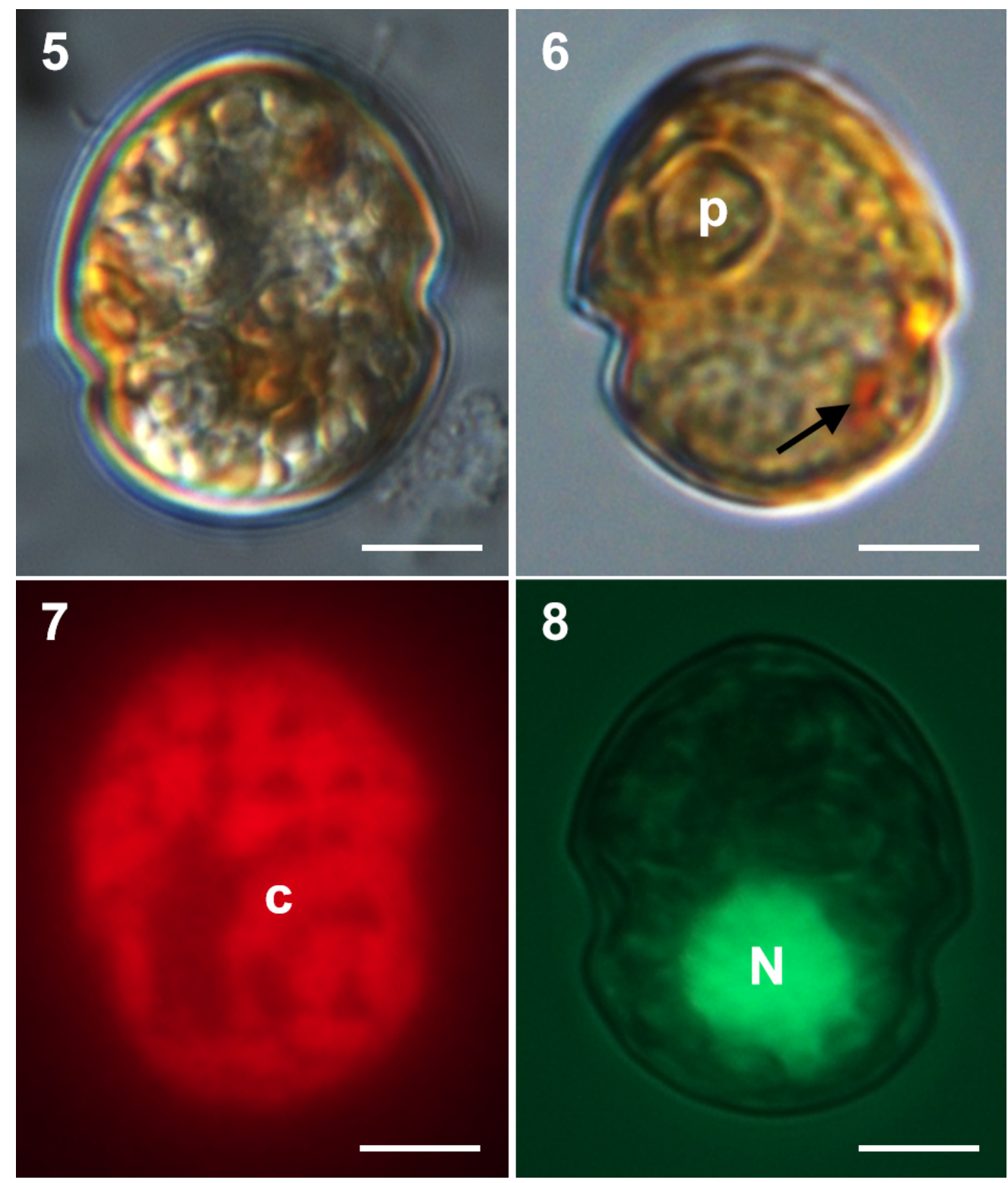

Figs. 5-8. Light micrographs of cells of Caladoa arcachonensis strain TIO278 from France. Fig. 5. Ventral view showing a rounded epitheca and hypotheca with a post-equatorial cingulum. Fig. 6 . Lateral view showing a ring like pyrenoid $(p)$ and a red eyespot (arrow). Fig.7. Epifluorescence image of a cell in ventral view showing the single reticulate chloroplast (c) in the periphery of the cell. Fig. 8. Epifluorescence image of a SYBR Green-stained cell showing a spherical nucleus $(\mathrm{N})$. Scale bars $=5 \mu \mathrm{m}$.

$80 \times 94 \mathrm{~mm}(300 \times 300$ DPI $)$ 

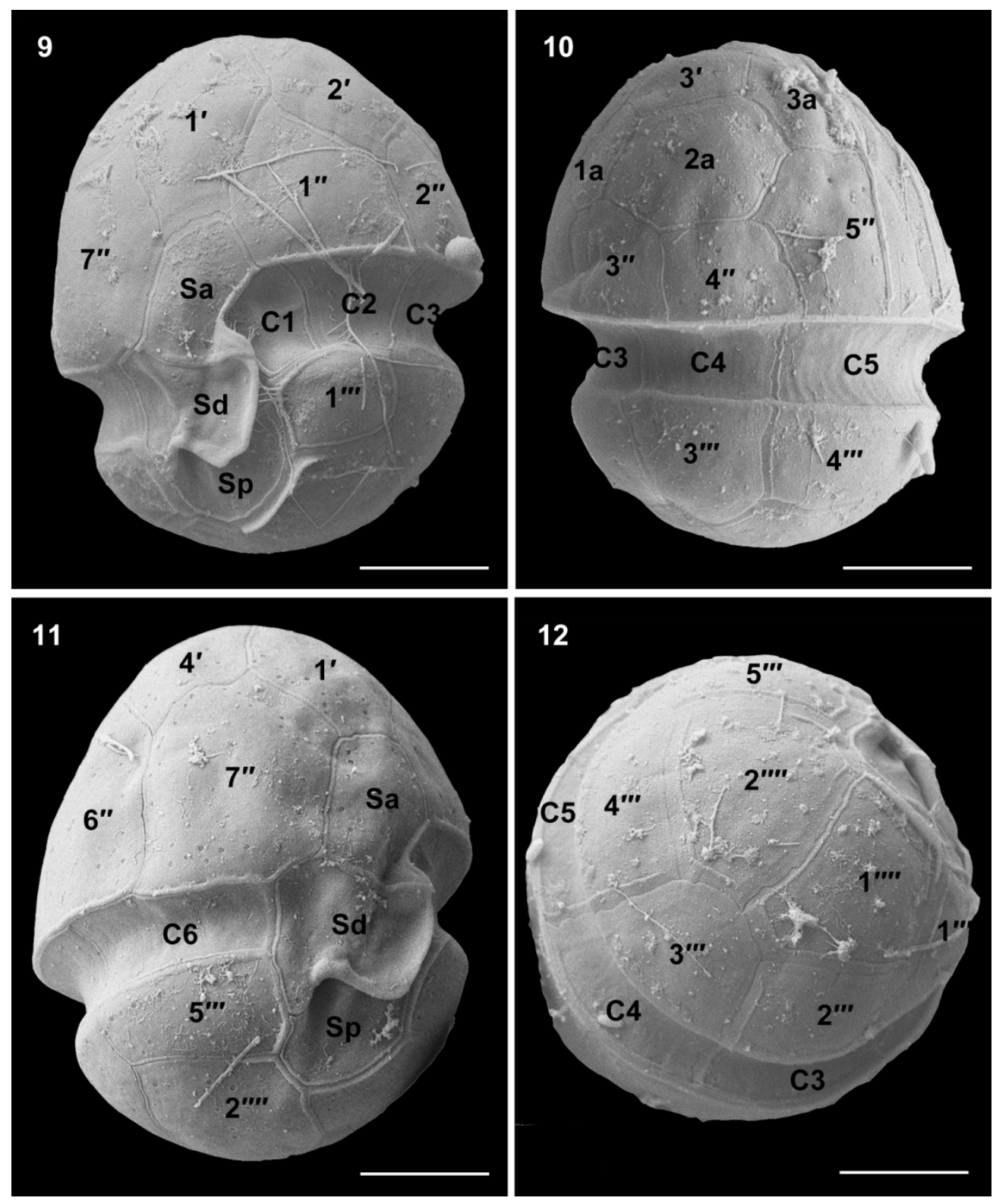

Figs. 9-12. Scanning electron micrographs of vegetative cells of Caladoa arcachonensis strain TIO278 from France. Fig. 9. Ventral view showing the first apical plate $\left(1^{\prime}\right)$, anterior sulcal plate (Sa), right sulcal plate $(\mathrm{Sd})$, posterior sulcal plate (Sp), and the first three cingular plates (C1 - C3). Fig. 10. Dorsal view showing three anterior intercalary plates $(1 a-3 a)$, three precingular plates $\left(3^{\prime \prime}-5^{\prime \prime}\right)$, three cingular plates (C3 C5) and two postcingular plates $\left(3^{\prime \prime \prime}, 4^{\prime \prime \prime}\right)$. Fig. 11 . Ventral-lateral right view showing two precingular plates $\left(6^{\prime \prime}, 7^{\prime \prime}\right)$, sixth cingular plate (C6) and fifth postcingular plate $\left(5^{\prime \prime \prime}\right)$. Fig. 12. Dorso-antapical view showing five postcingular plates $\left(1^{\prime \prime \prime}-5^{\prime \prime \prime}\right)$ and two antapical plates $\left(1^{\prime \prime \prime \prime}, 2^{\prime \prime \prime \prime}\right)$ of similar size. Scale bars $=5 \mu m$.

\section{$170 \times 205 \mathrm{~mm}(300 \times 300$ DPI $)$}



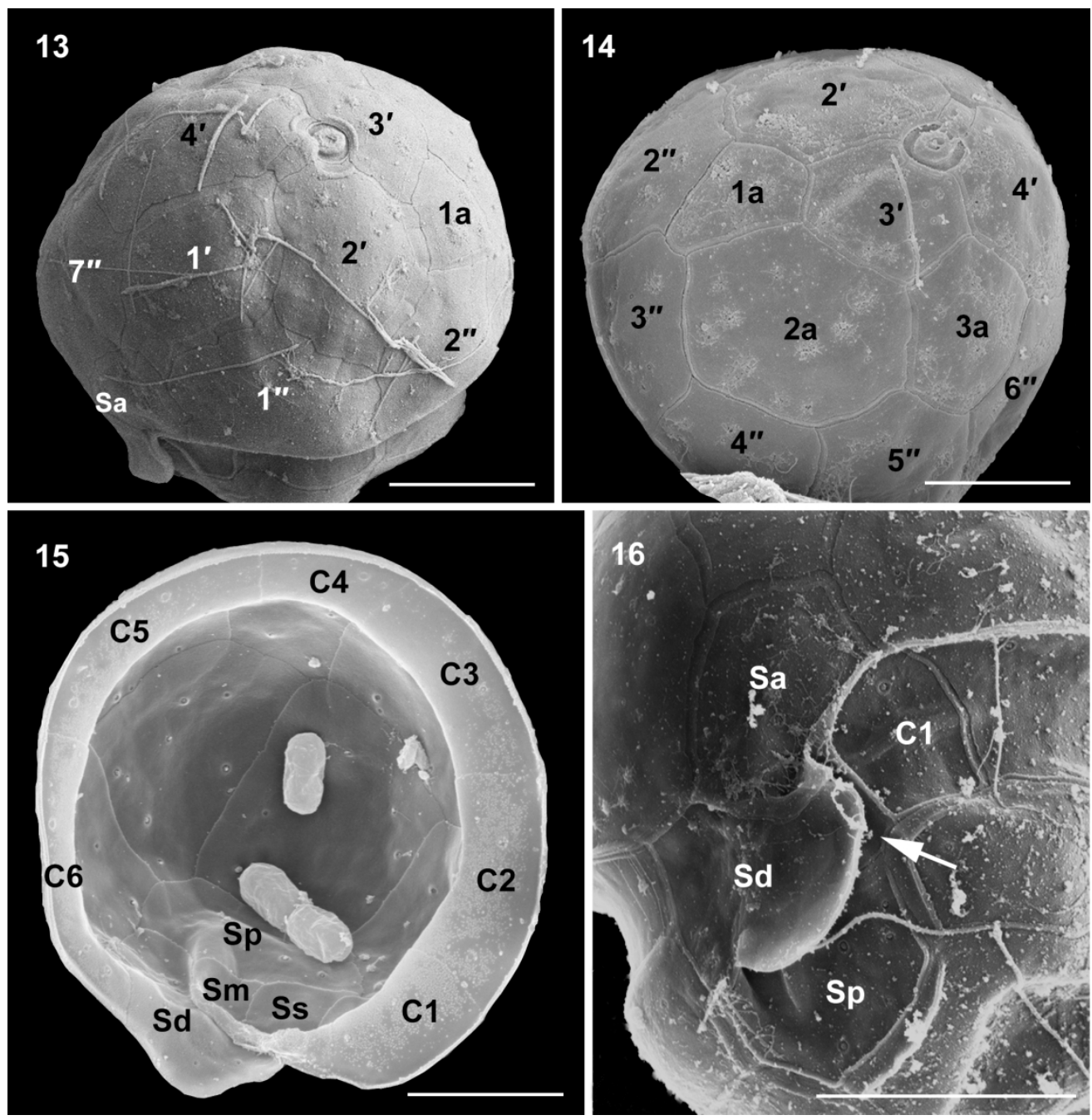

Figs. 13-16. Scanning electron micrographs of vegetative cells of Caladoa arcachonensis strain TIO278 from France. Fig. 13. Ventro-apical view showing four apical plates $\left(1^{\prime}-4^{\prime}\right)$, the anterior sulcal plate (Sa), the first anterior intercalary plate $(1 \mathrm{a})$ and three precingular plates $\left(1^{\prime \prime}, 2^{\prime \prime}, 7^{\prime \prime}\right)$. Fig. 14 . Dorso-apical view showing three apical plates $\left(2^{\prime}-4^{\prime}\right)$, three anterior intercalary plates $(1 a-3 a)$ and five precingular plates $\left(2^{\prime \prime}-6^{\prime \prime}\right)$. Fig. 15. Internal view of the hypotheca showing six cingular plates $(\mathrm{C} 1-\mathrm{C} 6)$ and right sulcal plate (Sd), left sulcal plate (Ss), median sulcal plate $(\mathrm{Sm})$ and posterior sulcal plate (Sp). Fig. 16. Sulcal area showing the first cingular plate (C1) and plates Sa, Sd, Sp and Ss (arrow). Scale bars $=5 \mu \mathrm{m}$.

$170 \times 173 \mathrm{~mm}(300 \times 300 \mathrm{DPI})$ 

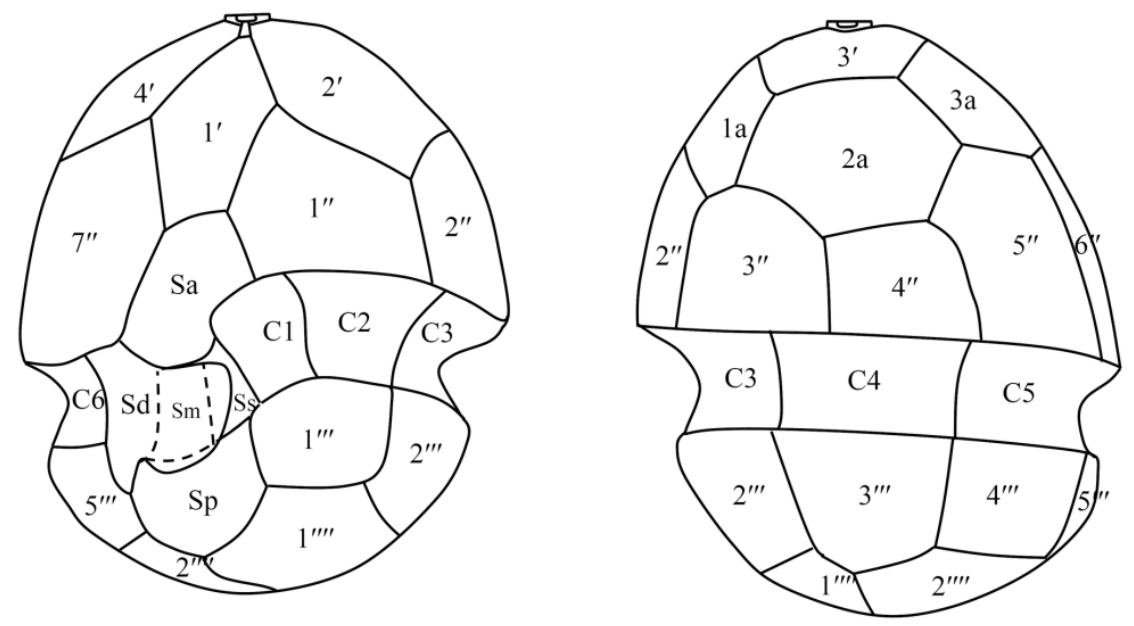

19
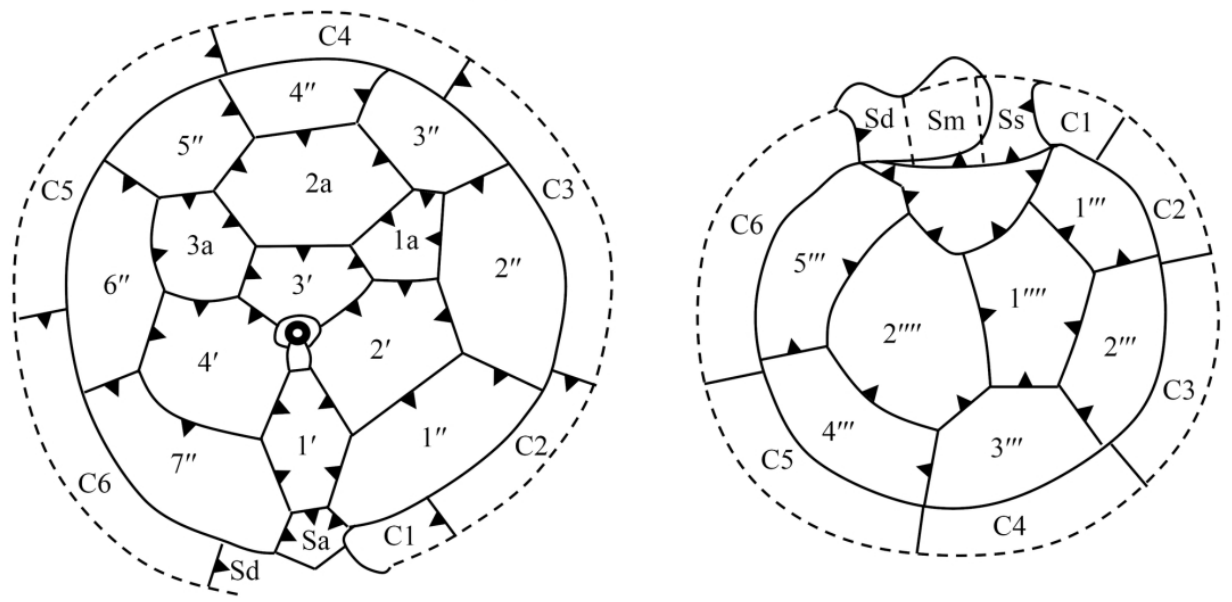

Figs. 17-20. Schematic drawings of thecal plate patterns of Caladoa arcachonensis. Fig. 17. Ventral view. Fig. 18. Dorsal view. Fig. 19. Apical view showing plate overlap patterns. Fig. 20. Antapical view showing plate overlap patterns.

$179 \times 191 \mathrm{~mm}(300 \times 300 \mathrm{DPI})$ 

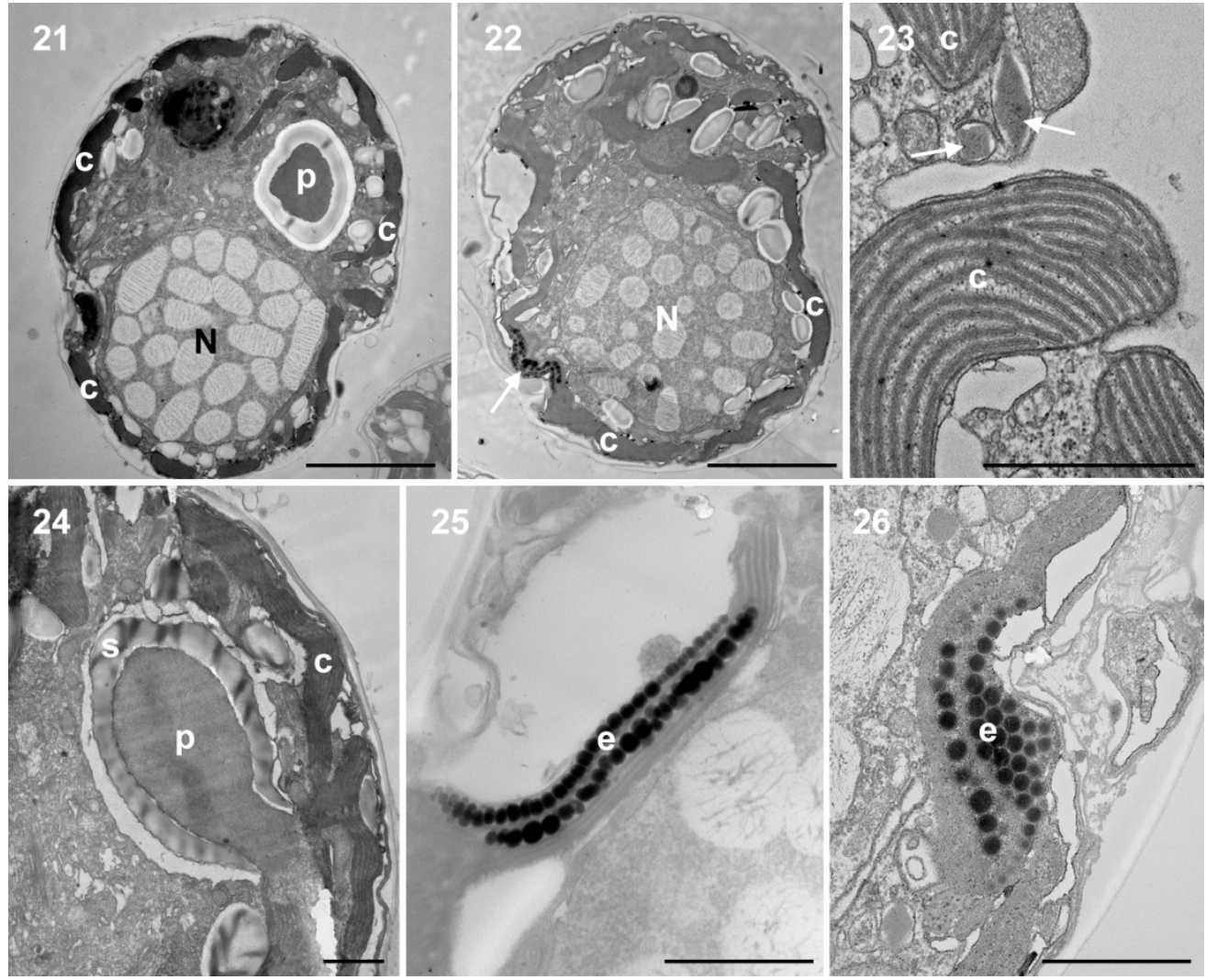

Figs. 21-26. Transmission electron micrographs of vegetative cells of Caladoa arcachonensis strain TIO278 from France. Figs. 21, 22. Transverse section through the cell showing a large nucleus (N), a stalked pyrenoid (p), a single chloroplast (c) in the periphery of the cell and an eyespot (arrow). Fig. 23. The chloroplast showing the thylakoids grouped in threes to form lamellae and several trichocysts (arrow). Fig. 24. Detail of the stalked pyrenoid (p) with dense matrices and a surrounding starch (s). Figs. 25, 26. The eyespot (e) located within a chloroplast (c) comprising several rows of globular lipids. Scale: Figs. $21,22=$ $5 \mu \mathrm{m}$, Figs. $23-26=1 \mu \mathrm{m}$.

$170 \times 138 \mathrm{~mm}(300 \times 300 \mathrm{DPI})$ 

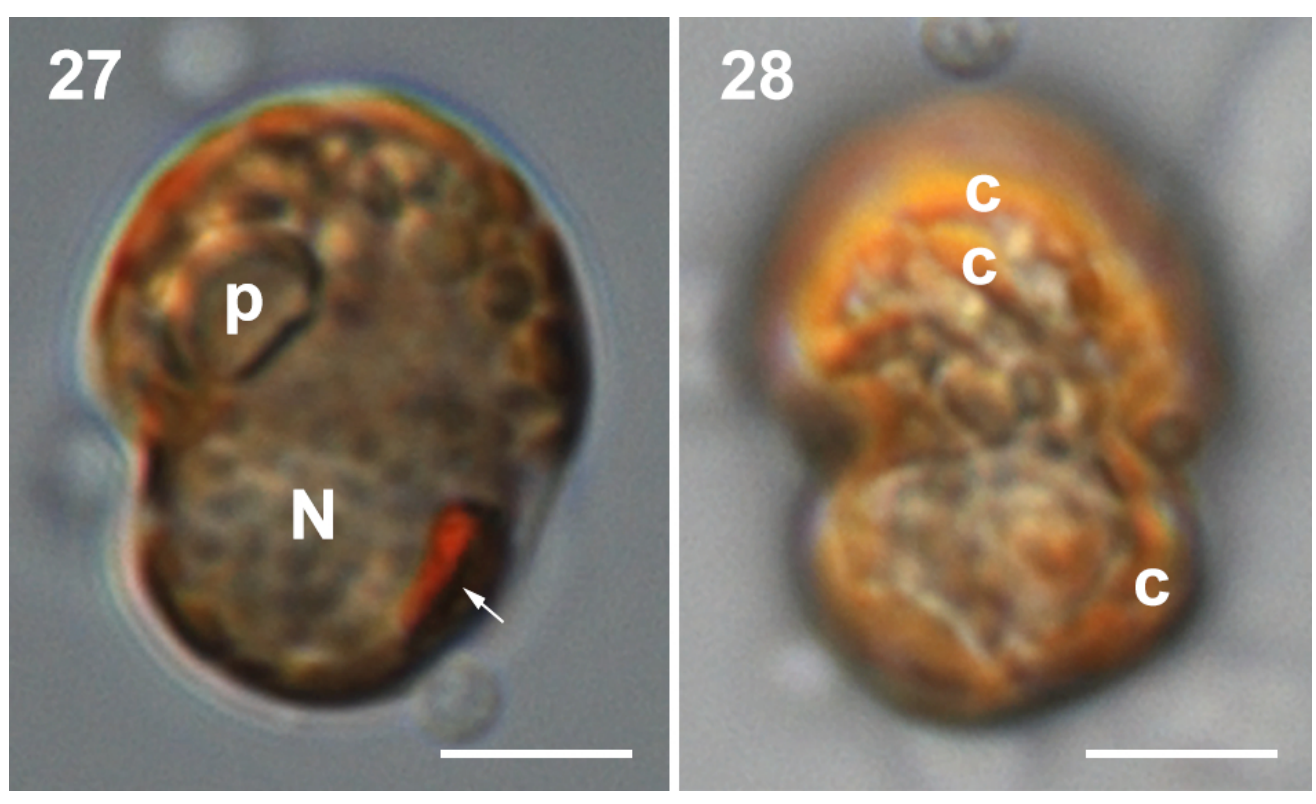

Figs. 27-28. Light micrographs of vegetative cells of Caladoa arcachonensis strain TIO339 from Indonesia. Fig. 27. Lateral view of a living cell showing a pyrenoid ( $p$ ), a nucleus (N) and an eyespot (arrow). Fig. 28. Dorwal view of a living cell showing a single chloroplast forming a network. Scale bars $=5 \mu \mathrm{m}$.

$$
80 \times 47 \mathrm{~mm}(300 \times 300 \mathrm{DPI})
$$



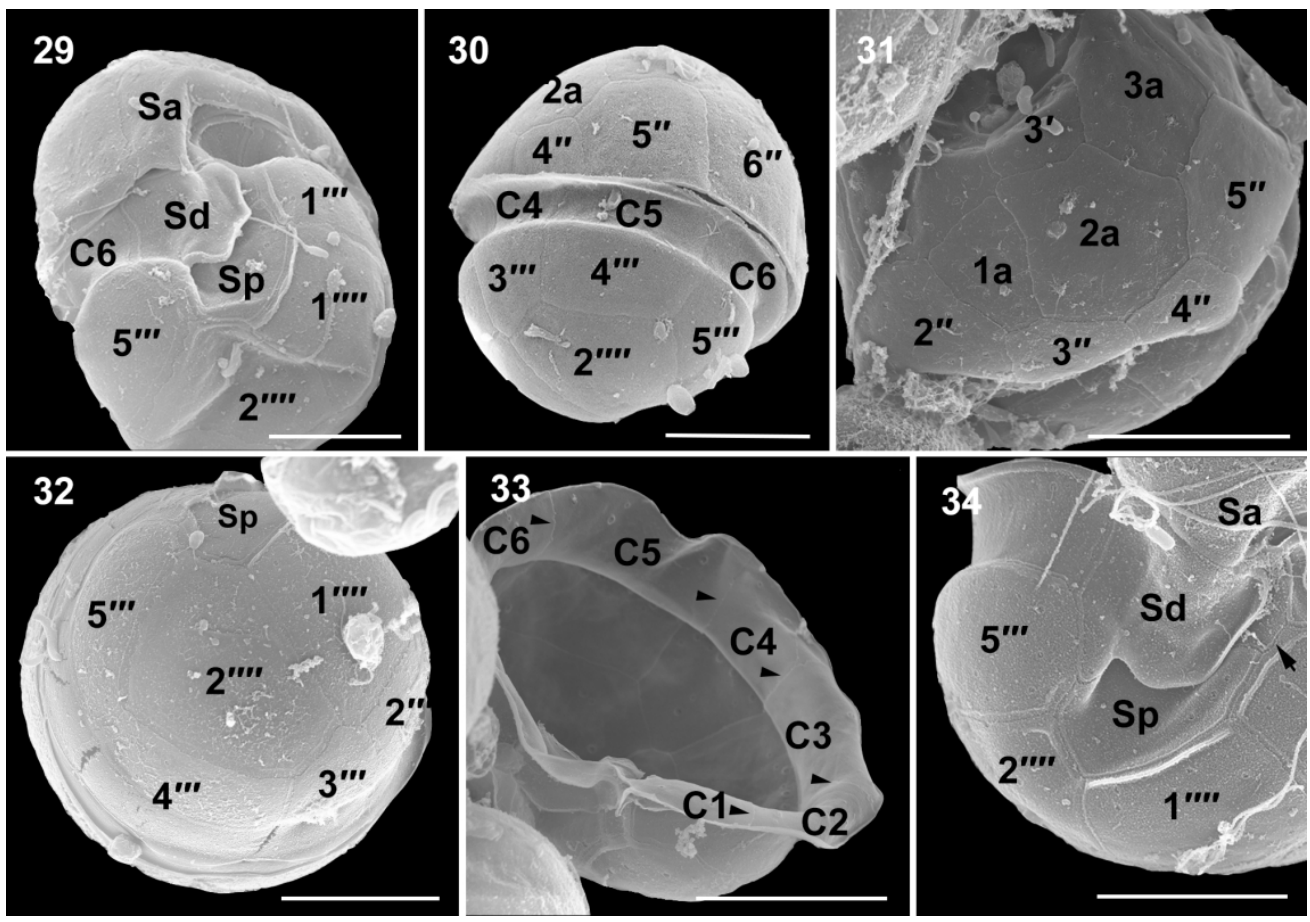

Figs. 29-34. Scanning electron micrographs of vegetative cells of Caladoa arcachonensis strain TIO339 from Indonesia. Fig. 29. Ventro-antapical view showing the anterior sulcal plate (Sa), the right sulcal plate (Sd), posterior sulcal plate (Sp), two postcingular plates $\left(1^{\prime \prime \prime}, 5^{\prime \prime \prime}\right)$ and two antapical plates $\left(1^{\prime \prime \prime \prime}, 2^{\prime \prime \prime \prime}\right)$. Fig. 30.

Dorsal view showing three precingular plates $\left(4^{\prime \prime}-6^{\prime \prime}\right)$, three cingular plates (C4 - C6) and three postcingular plates $\left(3^{\prime \prime \prime}-5^{\prime \prime \prime}\right)$. Fig. 31 . Dorso-apical view showing four precingular plates $\left(2^{\prime \prime}-5^{\prime \prime}\right)$, three anterior intercalary plates $(1 a-3 a)$. Fig. 32. Antapical view showing four postcingular plates $\left(2^{\prime \prime \prime}-5^{\prime \prime \prime}\right)$, plate Sp and two antapical plates $\left(1^{\prime \prime \prime}, 2^{\prime \prime \prime \prime}\right)$ of similar size. Fig. 33. Internal view of the hypotheca showing six cingular plates (C1 - C6). Fig. 34. The sulcus showing Sa, Sd, Sp and left sulcal plate (arrow). Scale bars

$$
=5 \mu \mathrm{m} \text {. }
$$

$170 \times 118 \mathrm{~mm}(300 \times 300 \mathrm{DPI})$ 


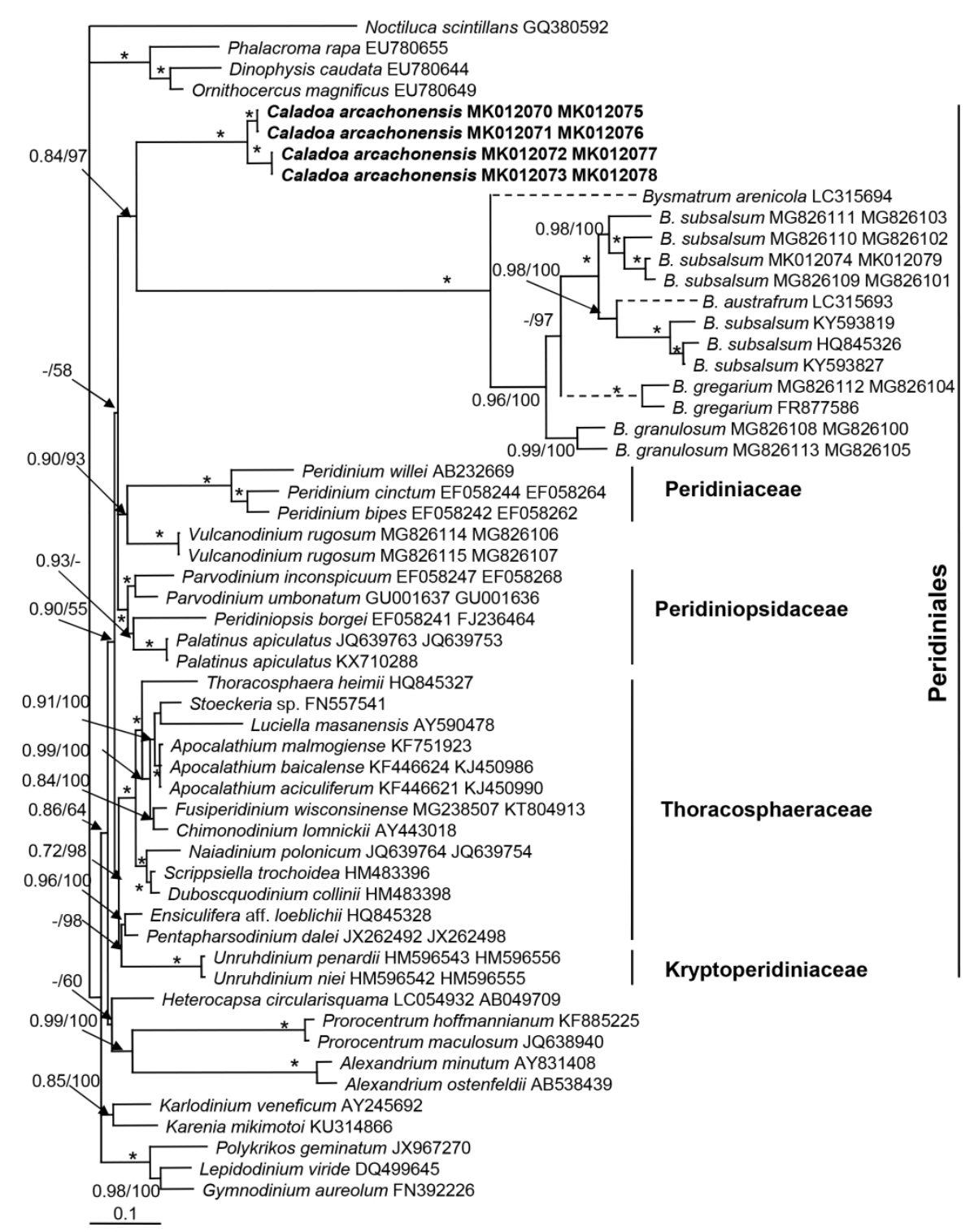

Fig. 35. Phylogeny of Caladoa inferred from concatenated SSU and partial LSU rDNA sequences using maximum likelihood (ML). New sequences are indicated in bold. Branch lengths are drawn to scale, with the scale bar indicating the number of nucleotide substitutions per site. Numbers on branches are statistical support values to clusters on the right of them (left: ML bootstrap support (BS) values; right: Bayesian posterior probabilities (BPP). Bootstrap support values $>50 \%$ and Bayesian posterior probabilities above 0.7 are shown. Asterisk indicates maximal support (ML BS $=100 \%$ and $B P P=1.00)$.

$196 \times 254 \mathrm{~mm}(300 \times 300 \mathrm{DPI})$ 